Prepared for South Bay Salt Pond Restoration Project

\title{
Phase 1 Studies Summary of Major Findings of the South Bay Salt Pond Restoration Project, South San Francisco Bay, California
}

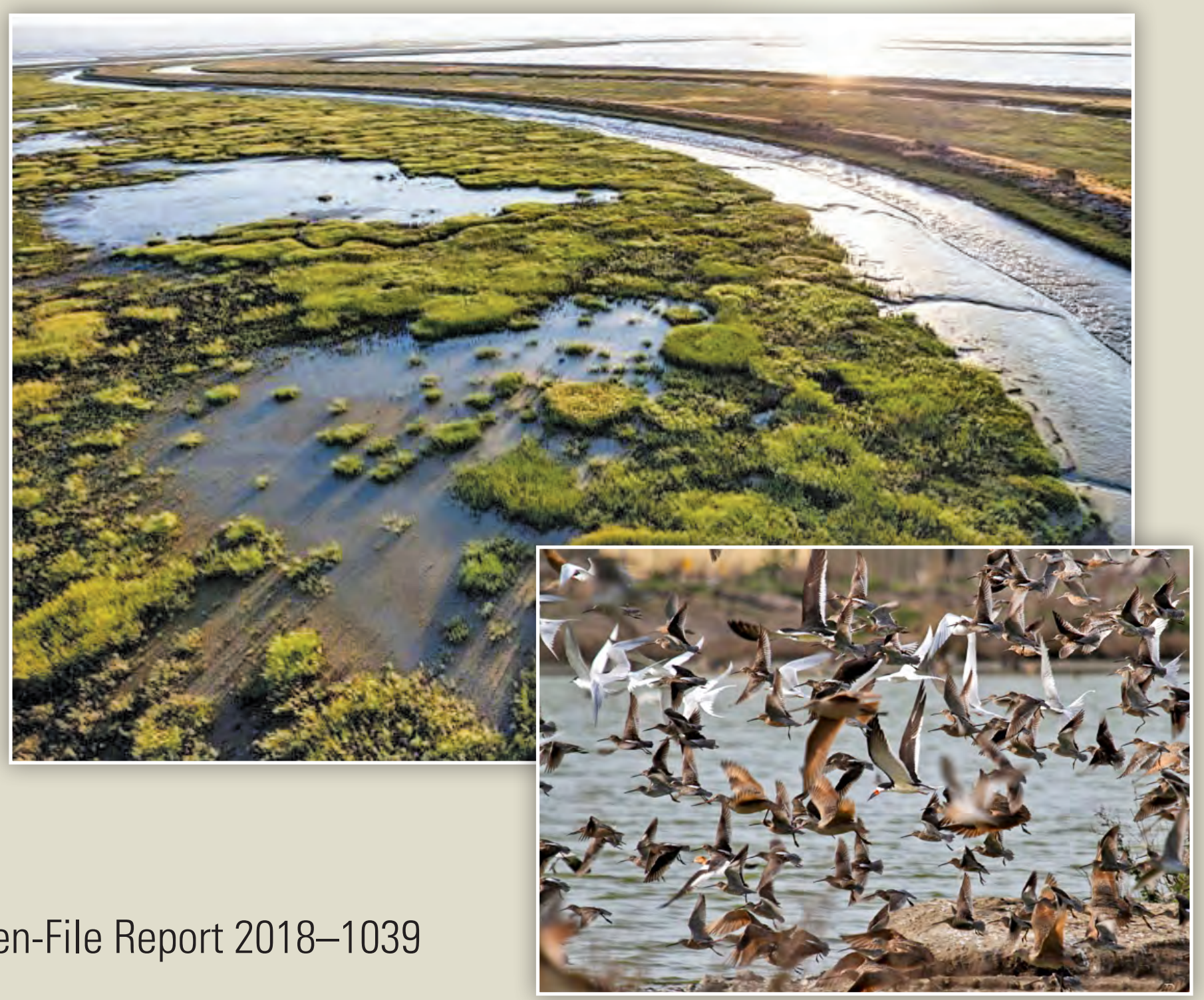

U.S. Department of the Interior

U.S. Geological Survey 


\section{Cover:}

Upper photograph: Pond A21 of the South Bay Salt Pond Restoration Project area, San Francisco, California, looking westward from northeastern corner of pond. (Photograph by Chris Benton, University of California, Berkeley, July 2014.)

Lower photograph: Black simmer (Rynchops niger) flying amid shorebirds and terns at Redwood Shores. (Photograph by M. Bruce Grosjean, Pelican Media, 2012.) 


\section{Phase 1 Studies Summary of Major Findings of the South Bay Salt Pond Restoration Project, South San Francisco Bay, California}

By Laura Valoppi

Prepared for South Bay Salt Pond Restoration Project

Open-File Report 2018-1039

U.S. Department of the Interior

U.S. Geological Survey 


\title{
U.S. Department of the Interior RYAN K. ZINKE, Secretary
}

\section{U.S. Geological Survey \\ William H. Werkheiser, Deputy Director \\ exercising the authority of the Director}

\author{
For more information on the USGS—-the Federal source for science about the Earth, \\ its natural and living resources, natural hazards, and the environment-visit \\ https://www.usgs.gov/ or call 1-888-ASK-USGS (1-888-275-8747). \\ For an overview of USGS information products, including maps, imagery, and publications, \\ visit https:/store.usgs.gov.
}

Any use of trade, firm, or product names is for descriptive purposes only and does not imply endorsement by the U.S. Government.

Although this information product, for the most part, is in the public domain, it also may contain copyrighted materials as noted in the text. Permission to reproduce copyrighted items must be secured from the copyright owner.

Suggested citation:

Valoppi, L., 2018, Phase 1 studies summary of major findings of the South Bay Salt Pond Restoration Project, South San Francisco Bay, California: U.S. Geological Survey Open-File Report 2018-1039, 58 p., plus appendixes, https://doi.org/10.3133/ofr20181039.

ISSN 2331-1258 (online) 


\section{Acknowledgments}

Financial support for the Lead Scientist position in the U.S. Geological Survey was provided by the U.S. Geological Survey, Western Ecological Research Center, the California Coastal Conservancy, and the U.S. Fish and Wildlife Service.

The Science Team for their knowledge, skill, dedication, and willingness to engage in an adaptive management process (current principal investigators, in alphabetical order):

Josh Ackerman, U.S. Geological Survey

Kristin Byrd, U.S. Geological Survey

John Callaway, University of San Francisco

Susan De La Cruz, U.S. Geological Survey

Brian Fulfrost, Brian Fulfrost and Associates

James Hobbs, University of California, Davis

Bruce Jaffe, U.S. Geological Survey

Stacy Moskal, U.S. Geological Survey

Janet Thompson, U.S. Geological Survey

Lynne Trulio, San Jose State University

Mark Mavin-DiPasqualie, U.S. Geological Survey

David Schoellhamer, U.S. Geological Survey

Darell Slotton, University of California, Davis

Karine Tokatlian, San Francisco Bay Bird Observatory

Yiwei Wang, San Francisco Bay Bird Observatory

Julian Wood, Point Blue Conservation Science 
The past and current Project Management Team for their unfailing commitment to working together to meet the goals of the South Bay Salt Pond Restoration Project and to using the best available science in their decisionmaking (current members, in alphabetical order):

Ariel Armbruster, Center for Collaborative Policy

Chris Barr, U.S. Fish and Wildlife Service

Rechelle Blank, Santa Clara Valley Water District

John Bourgeois, California State Coastal Conservancy

Brenda Buxton, California State Coastal Conservancy

Laura Choledenko, California State Coastal Conservancy

William DeJager, U.S. Army Corps of Engineers

Matt Gerhart, California State Coastal Conservancy

Conrad Jones, California Department of Fish and Wildlife

John Krause, California Department of Fish and Wildlife

Greg Martinelli, California Department of Fish and Wildlife

Anne Morkill, U.S. Fish and Wildlife Service

Pat Showalter, Santa Clara Valley Water District

Cheryl Strong, U.S. Fish and Wildlife Service

Rachel Tertes, U.S. Fish and Wildlife Service

Reviews of draft versions of this report were done by John Bourgeois, Cheryl Strong, Brenda Buxton, Ariel Ambruster, the Science Team, and peer reviewers Doug Barnum, U.S. Geological Survey and Sandra Scoggins of the San Francisco Bay Joint Venture have made this a better document. Thank you all for your comments, edits, and suggestions. 


\section{Contents}

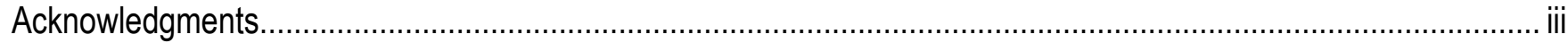

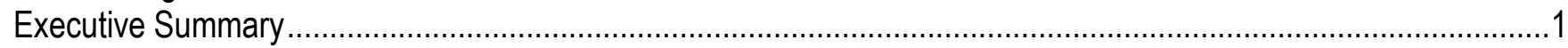

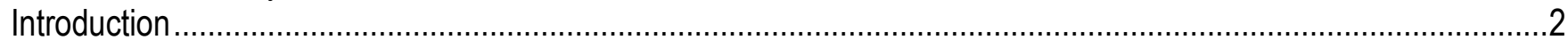

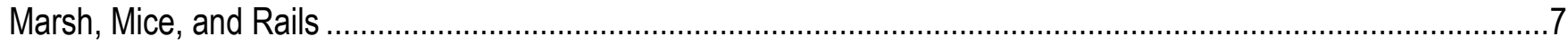

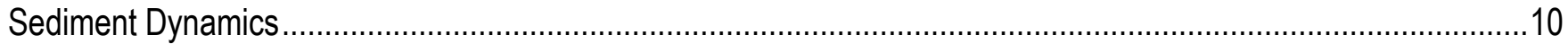

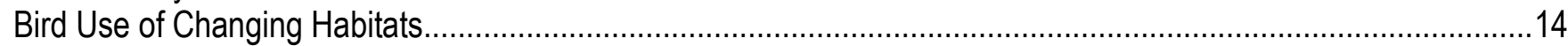

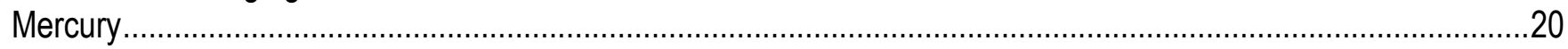

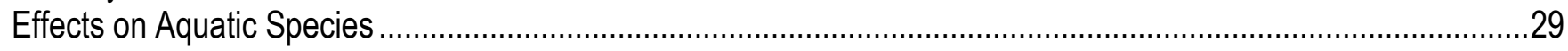

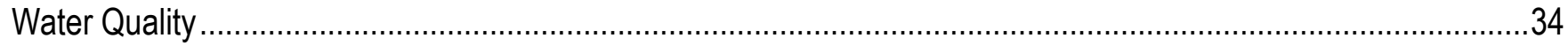

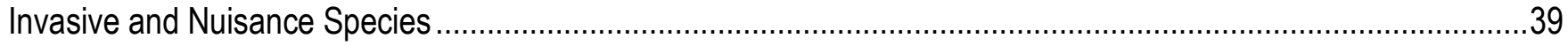

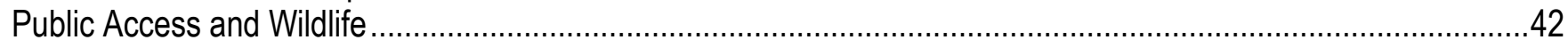

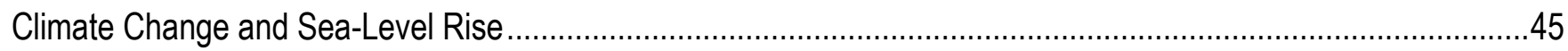

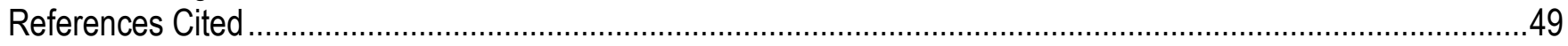

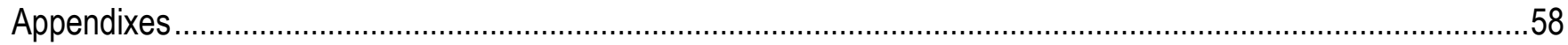

Appendix 1. Summary of Researcher/Manager Meeting, Milpitas, California, March 15, 2016 .......................58

Appendix 2. Survey of Managers on Phase 1 Studies ................................................................................58

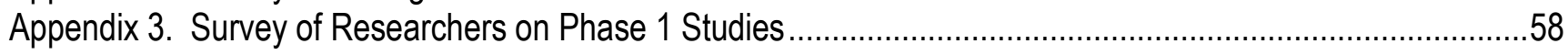

\section{Figures}

Figure 1. Map showing South Bay Salt Pond Restoration Project area and pond numbers, South San Francisco Bay, California

Figure 2. Diagram showing adaptive management staircase for tidal habitat restoration for the South Bay Salt Pond Restoration Project, South San Francisco Bay, California.

Figure 3. Expanded stoplight configuration for evaluating progress toward meeting the Adaptive Management Plan objectives of the South Bay Salt Pond Restoration Project, South San Francisco Bay, California .....

Figure 4. Graph showing net sediment flux estimated at Dumbarton Bridge, from the wastewater-treatment plants, and from local tributaries to South San Francisco Bay, California....................................................... 10

Figure 5. Graph showing sediment accumulation in Ponds A6 and A21, South San Francisco Bay, California .... 11

Figure 6: Graph showing overall South Bay Wintering Bird Abundance ................................................... 17

Figure 7. Photograph showing Pond A8, which is 40 feet wide with eight gates that can be independently opened or closed, South Bay Salt Pond Restoration Project, California....

Figure 8. Map showing Pond A8, Alviso Slough, and vicinity, South Bay Salt Pond Restoration Project, California

Figure 9. Graph showing history of Pond A8 gate opening and closing, South Bay Salt Pond Restoration Project, California 
Figure 10. Graph showing mercury concentrations in Forster's Tern eggs, South Bay Salt Pond Restoration Project, California, 2010-13.

Figure11. Graphs showing mercury concentrations in Forster's Tern and American Avocet eggs after opening the Pond A8 gates, South Bay Salt Pond Restoration Project, California, 2010-15

Figure 12. Graphs showing summer and winter assemblages of fish in Alviso Complex, South Bay Salt Pond Restoration Project, 2010-13

Figure 13. Graphs showing mean catch-per-unit-effort CPUE of fish and macro-invertebrates in fully tidal restoration ponds (Tidal Ponds) versus Sloughs in the Alviso Marsh and stations in Lower South Bay habitats sampled via otter trawls (upper graphs), and comparisons between Tidal Ponds and tidally muted (Managed Ponds) via beach seine (lower graphs), South Bay Salt Pond Restoration Project, California

Figure 14. Map showing location and features of water quality studies in Alviso Complex, South Bay

Salt Pond Restoration Project, California.

Figure 15. Graphs showing A8 gate operations effects on dissolved oxygen (DO) in Alviso Slough

(mid-slough station), South Bay Salt Pond Restoration Project, California.

\section{Conversion Factors}

U.S. customary units to International System of Units

\begin{tabular}{|c|c|c|}
\hline Multiply & By & To obtain \\
\hline \multicolumn{3}{|c|}{ Length } \\
\hline inch (in.) & 2.54 & centimeter $(\mathrm{cm})$ \\
\hline foot $(\mathrm{ft})$ & 0.3048 & meter $(\mathrm{m})$ \\
\hline mile (mi) & 1.609 & kilometer $(\mathrm{km})$ \\
\hline \multicolumn{3}{|c|}{ Area } \\
\hline acre & 0.004047 & square kilometer $\left(\mathrm{km}^{2}\right)$ \\
\hline \multicolumn{3}{|c|}{ Volume } \\
\hline gallon (gal) & 3.785 & liter $(\mathrm{L})$ \\
\hline \multicolumn{3}{|c|}{ Mass } \\
\hline kilogram (kg) & 35.2739 & ounce (oz.) \\
\hline
\end{tabular}




\title{
Phase 1 Studies Summary of Major Findings of the South Bay Salt Pond Restoration Project, South San Francisco Bay, California
}

\author{
By Laura Valoppi
}

\section{Executive Summary}

The South Bay Salt Pond Restoration Project (Project) is one of the largest restoration efforts in the United States. It is located in South San Francisco Bay of California. It is unique not only for its size - more than 15,000 acres - but also for its location adjacent to one of the nation's largest urban areas, home to more than 4 million people (Alameda, Santa Clara, and San Mateo Counties). The Project is intended to restore and enhance wetlands in South San Francisco Bay while providing for flood management, wildlife-oriented public access, and recreation. Restoration goals of the project are to provide a mosaic of saltmarsh habitat to benefit marsh species and managed ponds to benefit waterbirds, throughout 3 complexes and 54 former salt ponds.

Although much is known about the project area, significant uncertainties remain with a project of this geographic and temporal scale of an estimated 50 years to complete the restoration. For example, in order to convert anywhere from 50 to 90 percent of the existing managed ponds to saltmarsh habitat, conservation managers first enhance the habitat of managed ponds in order to increase use by waterbirds, and provide migratory, wintering, and nesting habitat for more than 90 species of waterbirds. Project managers have concluded that the best way to address these uncertainties is to carefully implement the project in phases and learn from the outcome of each phase. The Adaptive Management Plan (AMP) identifies specific restoration targets for multiple aspects of the Project and defines triggers that would necessitate some type of management action if a particular aspect is trending negatively. U.S. Geological Survey (USGS) biologist Laura Valoppi served as the project Lead Scientist and oversaw implementation of the AMP in coordination with other members of the Project Management Team (PMT), comprised of representatives from the California State Coastal Conservancy, California Department of Fish and Wildlife, the Santa Clara Valley Water District, the U.S. Army Corps of Engineers, and the U.S. Fish and Wildlife Service.

To implement the AMP, the PMT have selected and funded applied studies and monitoring projects to address key uncertainties. This information is used by the PMT to make decisions about current management of the project area and future restoration actions in order to meet project. 
This document summarizes the major scientific findings from studies conducted from 2009 to 2016, as part of the science program that was conducted in conjunction with Phase 1 restoration and management actions. Additionally, this report summarizes the management response to the study results under the guidance of the AMP framework and provides a list of suggested studies to be conducted in "Phase 2-A scorecard summarizing the Project's progress toward meeting the AMP goals for a range of Project objectives." The scoring to date indicates that the Project is meeting or exceeding expectations for sediment accretion and western snowy plover (Charadrius alexandrinus nivosus) recovery. There is uncertainty with respect to objectives for California gulls (Larus californicus), California least tern (Sternula antillarum), steelhead trout (Oncorhynchus mykiss), and regulatory water quality objectives. Water quality and algal blooms, specifically of the managed ponds, is indicated as trending negative. However, the vast majority of objectives are trending positive, including increased abundance for a number of bird guilds, increasing marsh habitat, maintenance of mudflats, visitor experience, estuarine fish numbers, and special-status marsh species numbers.

\section{Introduction}

The South Bay Salt Pond Restoration Project (Project) is one of the largest restoration efforts in the United States (fig. 1). It is located in South San Francisco Bay of California. It is unique not only for its size - more than 15,000 acres - but for its location adjacent to one of the nation's largest urban areas, home to more than 4 million people. The Project is intended to restore and enhance wetlands in South San Francisco Bay while providing for flood management and wildlife-oriented public access and recreation. Restoration goals of the project are to provide a mosaic of saltmarsh habitat to benefit marsh species and to provide managed ponds to benefit waterbirds, throughout 3 complexes and 54 former salt ponds. In order to minimize the loss of the historical use of managed ponds by birds, conservation managers first increase use of managed ponds by waterbirds over a smaller footprint, and maintain migratory, wintering, and nesting habitat for more than 90 species of waterbirds. If this can be accomplished, then anywhere from 50 to 90 percent of the existing managed ponds may be converted to saltmarsh habitat. In addition to uncertainties related to increasing the use of managed ponds by birds, there are a number of other uncertainties associated with implementing a project of this scale, such as whether there is sufficient sediment to support additional marsh habitat. The restoration efforts are estimated to take approximately 40 years to complete.

Although much is known about the project area (as documented in the 2007 Environmental Impact Statement/Report; U.S. Fish and Wildlife Service and California Department of Fish and Game, 2007), significant uncertainties remain with a project of this geographic and temporal scale. Project managers have concluded that the best way to address these uncertainties is to carefully implement the project in phases and to learn from the results. How this will be done as described in the Adaptive Management Plan (AMP) by Trulio and others (2007). U.S. Geological Survey (USGS) biologist Laura Valoppi served as the project's Lead Scientist and oversaw implementation of the AMP in coordination with other members of the Project Management Team (PMT), which included the Lead Scientist and representatives from the Santa Clara Valley Water District, U.S. Fish and Wildlife Service, the California Coastal Conservancy, California Department of Fish and Wildlife, the U.S. Army Corps of Engineers, and the Santa Clara Valley Water District. 
To implement the AMP, the PMT selected and funded a series of applied studies and monitoring projects to generate information about the Project's impacts. This information is used by the PMT to make decisions about current management of the project area and future restoration actions in order to meet project objectives. The applied studies and monitoring is conducted by the Science Team, comprised of researchers from the USGS, universities, non-profit and consultant organizations.

Not only is adaptive management essential to keeping the project on track towards meeting its objectives, it is the primary tool identified in the Environmental Impact Statement and Report (EIS/R; U.S. Fish and Wildlife Service and California Department of Fish and Game, 2007) for avoiding significant impacts to the environment. Adaptive management (and its associated information collection) provides project managers information and data that increases their understanding of the restored system, and provides some answers to key questions. Responses to unanticipated changes can be based on data and a better understanding of the habitats that are managed and restored. For these reasons, adaptive management is integral to the project and restoration proceeds following support for the applied studies and monitoring per the AMP.

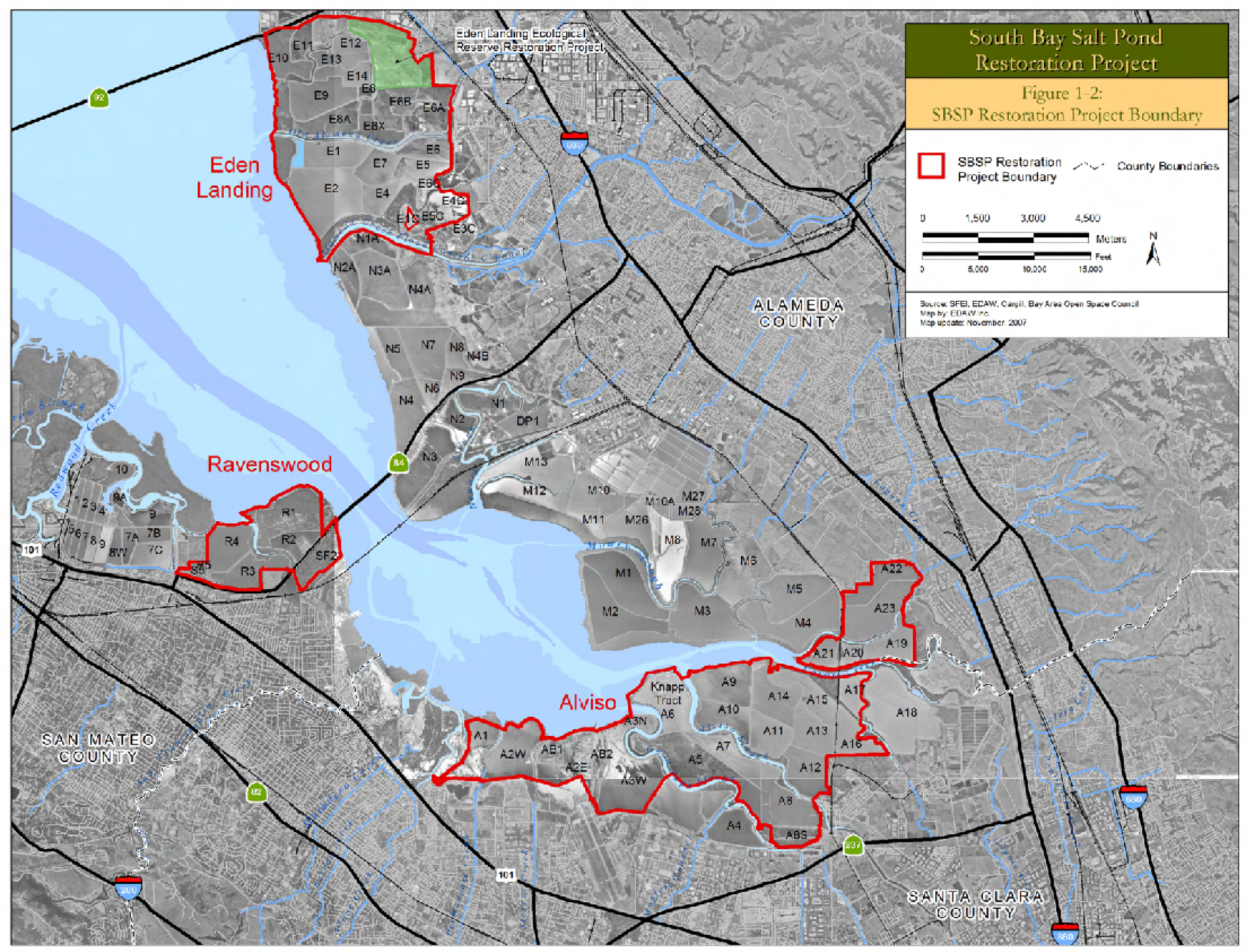

Figure 1. Map showing South Bay Salt Pond Restoration Project area and pond numbers, South San Francisco Bay, California. Eden Landing complex is owned and operated by the California Department of Fish and Wildlife as part of the Eden Landing Ecological Reserve. The Ravenswood and Alviso Complexes are owned and operated by the U.S. Fish and Wildlife Service as part of the Don Edwards San Francisco Bay National Wildlife Refuge. 
The Project developed a number of visions for what the restored ecosystem could look like in 50 years. In particular, the EIS/R for the Project evaluated (1) a 50 percent tidal:50 percent managed pond alternative in which approximately 50 percent of the Project area is returned to tidal action and 50 percent is managed as ponded habitat, and (2) a 90 percent tidal:10 percent managed pond. The Project managers agreed that, due to the many uncertainties, the mix of habitats that will optimally meet the Project objectives - including the amount of tidal restoration and its location — cannot be predicted at this time. Given this, the Project will implement restoration and management in phases and will use an adaptive management process for determining how far the system can move toward tidal restoration and associated marsh habitats, while still meeting the Project objectives. The adaptive management staircase in (fig. 2) is a conceptual view of this process. Adaptive management will provide the information needed to determine how far to proceed along the staircase and at what pace. Implicit in the staircase and the Project's core mission is that the Project will continue to add tidal habitat to the system, so long as the other Project objectives are met. Another possibility is that the Project might stop adding tidal habitat before 50 percent of the Project area is returned to tidal action, if substantial unanticipated impacts are identified.

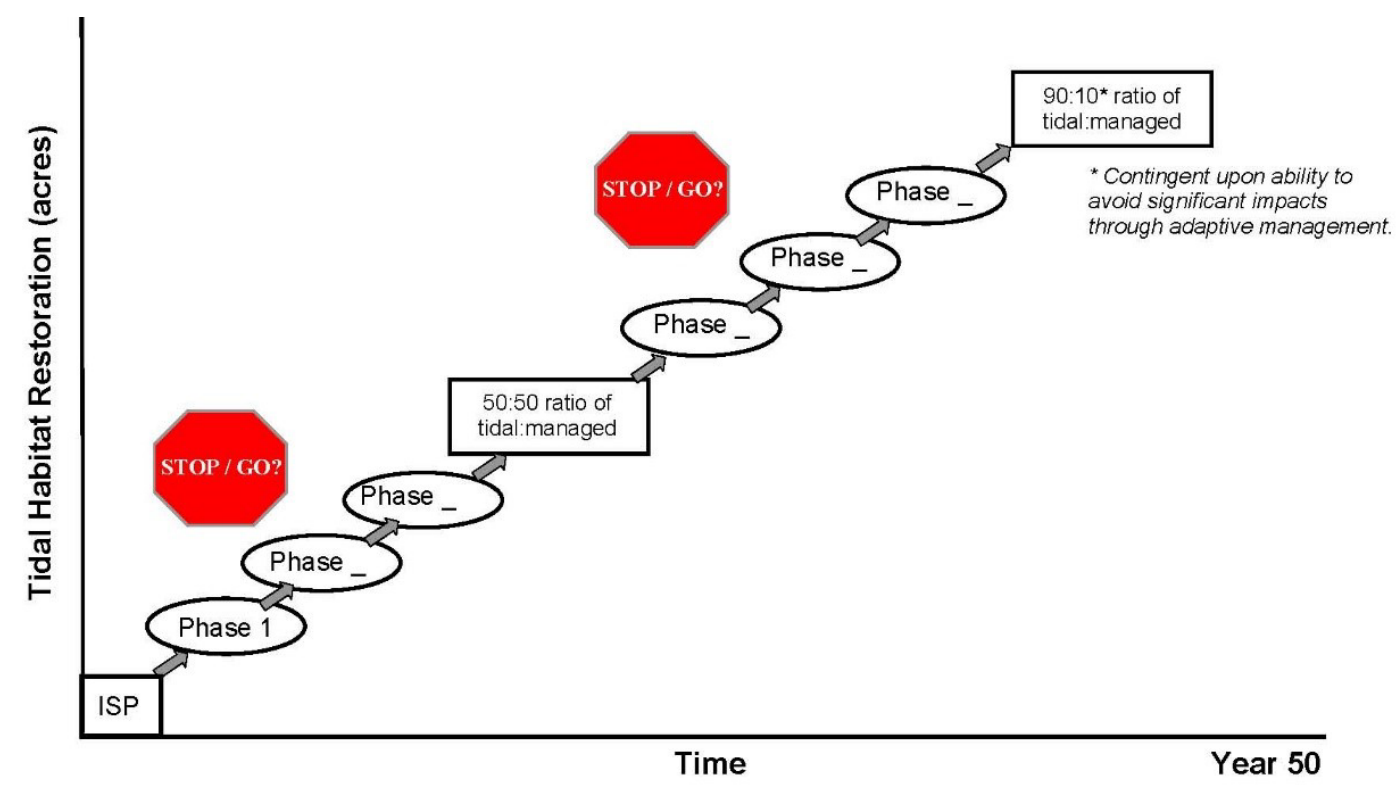

Figure 2. Diagram showing adaptive management staircase for tidal habitat restoration for the South Bay Salt Pond Restoration Project, South San Francisco Bay, California. ISP, Interim Stewardship Plan, where water control structures were added to the former salt ponds, allowing bay water in. 
A number of key uncertainties are identified in the Adaptive Management Plan (AMP), such as:

- Sediment dynamics: The extent to which tidal marsh restoration inside the ponds might result in the loss of slough and Bay tidal mudflat habitat outside of the Project ponds.

- Bird use of changing habitats: The extent to which tidal marsh species can be recovered while maintaining the diversity and abundance of nesting and migratory waterbirds observed prior to the Project.

- Effects on non-avian species: The extent to which restoration and management may affect fish and other critical species in the South Bay ecosystem.

- Mercury: The extent to which Project restoration and management actions might result in an increase in bioavailable mercury in the food chain above pre-Project concentrations.

- Water quality: The effects of pond management regimes on slough and Bay water quality and important aquatic species.

- Invasive and nuisance species increase: The effects of invasive species, especially invasive cordgrass (Spartina) hybrids, red fox (Vulpes Vulpes), California gulls, and mosquitoes (Anopheles spp.).

- Public access and wildlife: Ways in which public access and recreation can be integrated into the Project without negatively affecting wildlife.

Additionally, climate change and associated sea-level rise, although not specifically identified in the AMP as an uncertainty, have been the focus of research and management actions to begin enacting resiliency strategies to ameliorate some of the projected impacts. Appendix 3 of the AMP Report (EIS/R; U.S. Fish and Wildlife Service and California Department of Fish and Game, 2007) lists several project objectives associated with the key uncertainties and identifies restoration targets for that particular objective. The AMP also describes triggers that identify conditions that would result in a management action response. A trigger is a change in a specific attribute of the ecosystem related to a particular objective. As an example, if the objective is for sufficient sediment to form a vegetated marsh, the target is for the rate of accretion of sediment in a pond restored to full tidal flows to be sufficient to support vegetated marsh within a specified timeframe; the trigger would be if sediment accretion is not on a trajectory to form vegetated marsh in the expected timeframe. The management actions that result from a trigger could be reviews of the data to determine if the slower sediment accretion was due to restoration actions, studies of the effects of a slower development of vegetated marsh, or adjustments to the design of the restoration to increase sediment accretion in that pond. Several presentations have been given that describe how adaptive management is being applied for management decisions for the Project (Valoppi and Bourgeois, 2014; Valoppi and others, 2014a, 2014b, 2015). 
This report provides a summary of the PMT and Science Team evaluation of how well the Project is meeting the AMP targets for each objective and whether a trigger has been identified that would indicate the need for additional management action for the Project to stay on track to meet its goal. This report summarizes the results of that evaluation using an expanded stoplight configuration (fig. 3) to assess whether the Project is meeting expectations with respect to goals of the AMP.

\begin{tabular}{|c|l|}
\hline 0 & Meets/exceeds expectations \\
\hline 0 & Uncertain, trending positive \\
\hline 0 & Uncertain \\
\hline $\mathrm{O}$ & Uncertain, trending negative \\
\hline & Not meeting expectations \\
\hline
\end{tabular}

Figure 3. Expanded stoplight configuration for evaluating progress toward meeting the Adaptive Management Plan objectives of the South Bay Salt Pond Restoration Project, South San Francisco Bay, California.

Details of the basis for the Science Team and PMT scoring of each of the key uncertainties is provided in appendix 1, which summarizes a meeting held on March 15, 2016. Researchers from all disciplines involved and the management team met together to review the key research results to date, arrive at a consensus on a ranking of the progress on the AMP objectives, and develop a list of studies recommended for Phase 2 studies. Appendixes 2 and 3 contain a survey of managers and researchers respectively on the specific studies conducted as part of Phase 1, the utility of the studies to evaluate the management questions, the quality of the studies, and recommendations for Phase 2.

Each of the following sections contain a summary of the key findings of the applied studies and monitoring conducted during Phase 1 pertaining to subject matter of that section. References are provided at the end of the document, organized by section. Each section also contains the expanded stoplight score evaluating progress toward meeting the AMP objectives; a summary of the management actions taken based on the science findings; and a summary of needed studies for Phase 2 . Thus, each section focuses on a particular topic area and provides a comprehensive overview of the key uncertainties, the context for the issue, a summary of management responses to Phase 1 studies, an evaluation of progress to date toward the restoration goals, how managers adaptively managed during Phase 1, and needed studies to be conducted during Phase 2. 


\section{Marsh, Mice, and Rails}

Central to the Project is the restoration of former salt ponds back to the original salt marsh habitat. Salt marsh habitat provides many benefits to the human landscape in terms of improved flood protection, filtering of contaminants from water, and recreational opportunities (Goals Project, 2015). This habitat is also essential for the life history of at least 11 different species and subspecies of plants and wildlife, many of which are listed by the State and Federal governments as threatened or endangered (U.S. Fish and Wildlife Service, 2013). In particular, two species, the federally endangered Ridgway's rail (Rallus obsoletus; formerly known as California clapper rail), and the salt marsh harvest mouse (reithrodontomys raviventris), can only live in a saltmarsh environment, and both are keystone species for salt marsh habitat. The rail and mouse now exist in about 10 percent of the area they formerly occupied, primarily due to loss and conversion of the salt marsh habitat they rely upon (Liu and others, 2012; U.S. Fish and Wildlife Service, 2013). Restoration of salt marsh habitat is critical to the recovery of these species.

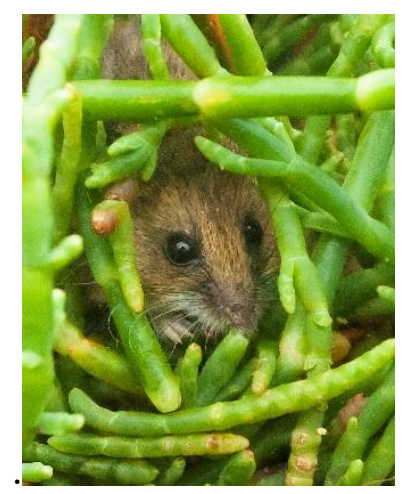

Salt Marsh Harvest Mouse in pickleweed. Photograph by Pelican Media.

The first construction of the Project was in spring 2006, when the "Island Ponds" (Ponds A19, A20, and A21) were breached along Coyote Creek, and tidal waters flowed into the ponds. Managers chose these ponds as they were relatively isolated and small, and did not pose a threat of flooding of neighboring parcels if breached. These ponds were breached in order to begin an early experiment in restoration, to study how quickly the marsh developed and how quickly tidal marsh species would occupy the habitat. In less than 10 years, Pond A21 had enough sediment that 118 acres of marsh plants, such as cordgrass (Spartina spp.) and pickleweed (Salicornia spp.), became established. The amount of sediment coming in was monitored (see section, "Sediment"), as was the establishment of salt marsh plant species. Ponds A19 and A20 have not had marsh habitat establish as quickly; Pond A20 has 33 acres of vegetation established, Pond A19 has 14 acres (Santa Clara Valley Water District and U.S. Fish and Wildlife Service, 2015).

In July 2014, staff from the San Francisco Estuary Invasive Spartina Project (http://www.spartina.org/) spotted a Ridgway's rail inside Pond A21. In 2015, the U.S. Fish and Wildlife Service began to survey these ponds for the presence of the Ridgway's rail or the salt marsh harvest mouse. In July of that year, several of the endangered mice were trapped, and breeding rails were documented in Pond A21. 
The presence of these two keystone species occurred sooner than had been expected - the AMP estimated that it would take at least 5-10 years for marsh vegetation to become established, and decades after substantial marsh vegetation was established before these species would inhabit the newly restored area.

Non-native, invasive cordgrass species of smooth cordgrass (Spartina alternifora) and its hybrids with the native California cordgrass (Spartina foliosa) has been the focus of an extensive identification and control program (San Francisco Estuary Invasive Spartina Project) throughout the San Francisco Bay, including within the Project area.

This invasive species poses a threat to native marsh habitat (Overton and others, 2014, 2015). The Project has coordinated removal of invasive cordgrass (Spartina) from the Project area with the Invasive Spartina Project. The Project has collaborated with the Invasive Spartina Project on revegetation of marsh plants, surveys for Ridgway's rail, and other measures to offset declines in marsh habitat, on Project lands.

\section{Key Uncertainty}

How do Ridgway's rails (California clapper rail) and (or) other key tidal habitat species (such as the salt mouse harvest mouse) respond to variations in tidal marsh habitat quality and what are the habitat factors contributing to that response?

Question 1. Is marsh vegetation establishment trending toward reference marsh quality?

Question 2. Does tidal marsh habitat for Ridgway's rails within the Project area meet recovery plan criteria for rail habitat? For numbers of rails?

Question 3. Does tidal marsh habitat for salt marsh harvest mice within the Project area meet recovery plan criteria for mice habitat? For number of mice?

Question 4. How do Ridgway's rails and/or other key tidal habitat species respond to variations in tidal marsh habitat quality and what are the habitat factors contributing to that response?

\begin{tabular}{|l|l|l|}
\hline & $\begin{array}{l}\text { Key Uncertainty: How do Ridgway's rails (California clapper rail) and (or) other key } \\
\text { tidal habitat species (salt mouse harvest mouse) respond to variations in tidal marsh } \\
\text { habitat quality and what are the habitat factors contributing to that response? }\end{array}$ \\
\hline 1 & \begin{tabular}{l} 
Is marsh vegetation establishment trending toward reference marsh quality? \\
\hline 2
\end{tabular} & $\begin{array}{l}\text { Does tidal marsh habitat for Ridgway's rails within the Project area meet recovery plan } \\
\text { criteria for rail habitat? }\end{array}$ \\
\hline 3 & $\begin{array}{l}\text { Does the number of Ridgway's rails within the Project area meet recovery plan criteria } \\
\text { for number of rails? }\end{array}$ \\
\hline 4 & $\begin{array}{l}\text { Does tidal marsh habitat for salt marsh harvest mice within the Project area meet } \\
\text { recovery plan criteria for mice habitat? }\end{array}$ \\
\hline 5 & $\begin{array}{l}\text { Does the number of salt marsh harvest mice within the Project area meet recovery plan } \\
\text { criteria number of mice }\end{array}$ \\
\hline
\end{tabular}




\section{Management Responses to Phase 1 Studies}

- Marsh habitat has established sooner than the AMP predicted at Pond A21, so no additional restoration is planned.

- Marsh habitat in Ponds A19 and A20 has occurred more slowly so, as per the AMP, design of these ponds has been adjusted to construct additional breaches, lower portions of levees, and excavate pilot channels in order to increase tidal flows into the ponds. These restoration actions are being planned for Phase 2 of the restoration.

- Managers continue to coordinate with the Invasive Spartina Project to assess and control occurrences of Spartina hybrids.

\section{Needed Phase 2 Studies for Marsh, Mice, and Rails}

- Fund implementation and effectiveness of the weed management plan to control other invasive species such as pepperweed.

- Repeat satellite imagery techniques used for establishing baseline vegetation types and extent to assess landscape level changes from Phase 1 restoration actions. The AMP recommends doing this every 5 years, beginning 5 years after the restored area has reached vegetation colonization elevation.

$\circ$ Assess quality of the restored marsh by using adjacent established marshes as reference sites.

○ Conduct rail surveys baywide once the Invasive Spartina Project is no longer conducting surveys.

- Evaluate marsh restoration projects from other bay restoration sites to evaluate best practices for features such as upland transition zones/ecotones, marsh mounds, and revegetation. 


\section{Sediment Dynamics}

For the restored tidal marshes to be established and be self-sustaining over time, a certain amount of mud (sediment) must be available in the Bay waters. Nature's first step in creating a marsh is to build up enough sediment in a subsided pond to allow plants to grow, and so those sediments need to be suspended in Bay waters to reach the restoration site. This sediment also replenishes existing marshes and mudflats.

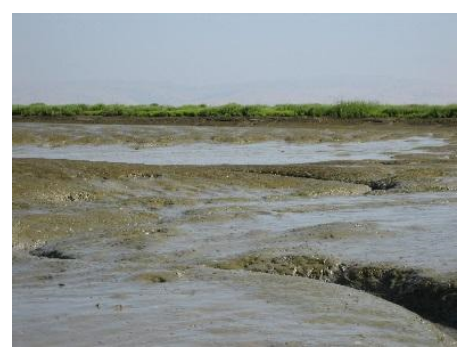

Sedimentation in Pond A21 after breach.

Photograph by Laura Valoppi, U.S. Geological Survey.

A USGS team led by David Schoellhamer has been monitoring the sediment movement (flux) in and out of South San Francisco Bay and has found flux to be variable from 2009 to 2011 (Schoellhamer, Shellenbarger, and others, 2013; Shellenbarger and others, 2013, 2014; Schoellhamer and others, 2015). In 2009, there was a net sediment flux going into South Bay of about 242,000 tons, while the following year there was only about 12,000 tons of sediment going into South Bay. In 2011, there was a substantial reversal in the direction of sediment, with 485,000 tons of sediment moving out of South Bay (fig. 4). Other studies by these researchers indicate that overall sediment in the San Francisco Bay started decreasing in the late 1990s, and it is unknown whether sediment supply will stay constant or continue to decrease (Schoellhamer, Wright, and others, 2013).

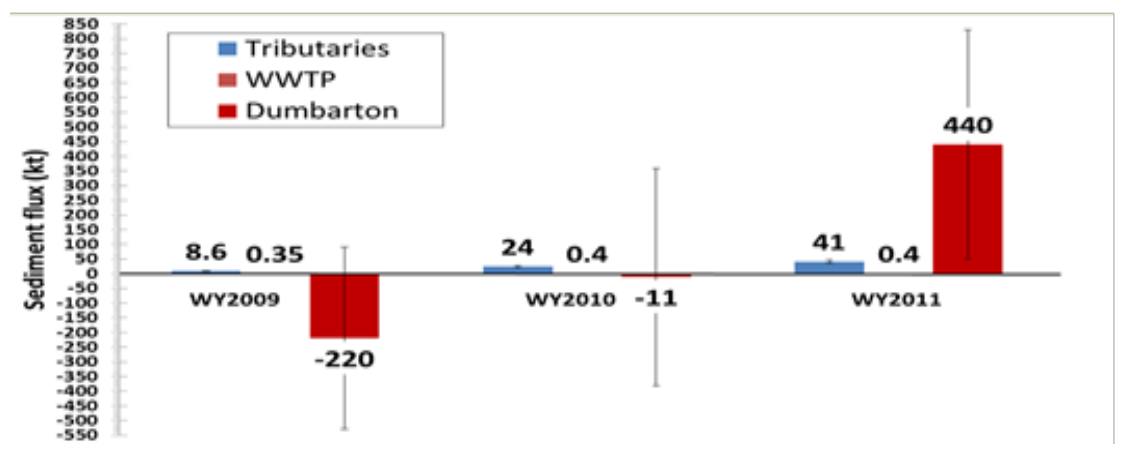

Figure 4. Graph showing net sediment flux estimated at Dumbarton Bridge, from the wastewater- treatment plants, and from local tributaries to South San Francisco Bay, California. Water year (WY) is from October 1 of that year to September 30 of the following year. Positive values indicate sediment flux out of South Bay. Negative values indicate sediment flux into South Bay. Graphic courtesy of Greg Shellenbarger. 


\section{Key Uncertainty}

Is there sufficient sediment available in the South Bay to support marsh development without causing unacceptable impacts to existing habitats?

Question 1. Will sediment accretion in restored tidal areas be adequate to create and to support emergent tidal habitat ecosystems within the 50 -year projected time frame?

Question 2. Will sediment movement into restored tidal areas significantly reduce habitat area and/or ecological functioning (such as plankton, benthic, fish, or bird diversity or abundance in the South Bay)?

Question 3. Will restoration activities always result in a net decrease in flood hazard?

During that same time period (2011), John Callaway of University of San Francisco showed very high sediment accumulation in Pond A6; this pond had only been re-opened to natural tidal flow in December 2010 (Callaway and others, 2009). Within 28 months, there was an average sediment deposition of $18.5 \mathrm{in}$. $(470 \mathrm{~mm})$ in 28 months, or about $8 \mathrm{in} / \mathrm{yr}$. The A6 sedimentation rate was even greater than the rapid rates seen at Pond A21, a 2006 restoration project. Pond A21 accumulated about 8 in. (about 203 millimeters) over 3 years in portions of the pond (fig. 5) (Callaway and others, 2013). Based on results from Ponds A6 and A21, we expect high rates of sedimentation to continue for future restored ponds in the South Bay. Both sites had rates of sediment accretion that are orders of magnitude higher than those found in higher elevation, well-developed tidal marshes. Both Ponds A6 and A21 are located in the Alviso Complex, an area that has subsided ponds, so higher accumulation rates were expected. Marsh habitat has become established in Pond A21 and on the higher elevations within Pond A6, indicating sufficient sediment is available to increase elevation to a level where marsh plants can colonize. Small areas of pickleweed have become established on the higher elevations of Ponds E9/E8A/E8X in Eden Landing, indicating the ponds are also accumulating sediment although the rate is not known. Overall Phase 1 marsh establishment has proceeded rapidly, despite fluctuations in annual sediment. Future studies could focus on understanding the variability in sediment coming into South Bay over time and sediment accumulation in Eden Landing and Ravenswood Complexes.

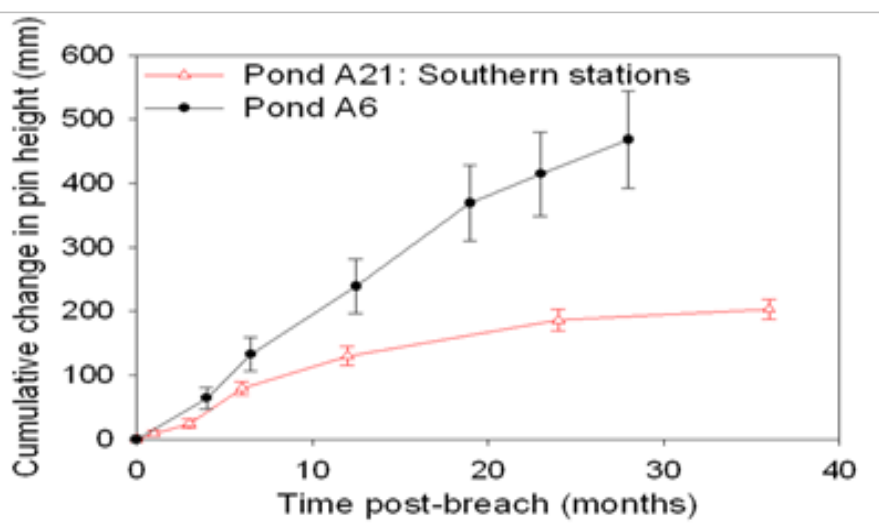

Figure 5. Graph showing sediment accumulation in Ponds A6 and A21, South San Francisco Bay, California. Graphic courtesy of John Callaway, University of San Francisco. 
In order to track future changes in habitat as restoration efforts progressed, Brian Fulfrost and associates conducted a 3 year project (2009-11) of obtaining satellite imagery to delineate vegetation, mudflats, and other habitat within a 33,000 acre area that encompassed the Project area, as well as the extensive mudflats and vegetated habitats south of the San Mateo Bridge (Fulfrost and others, 2012). More than 1,000 vegetation surveys were conducted in the field to ground-truth the habitat models that were developed from the satellite imagery to specific habitat classifications. This project was successful in characterizing and delineating baseline conditions for several habitat types, but not delineating mudflat habitat due to technical limitations. The chief limitation was matching the timing of the satellite fly-over with the tides-it was nearly impossible to have the satellite fly-over at the lowest tides in order to show the full extent of mudflat habitat. Mudflat habitat is valuable for foraging birds, especially during winter and migration seasons. This meant that a baseline of mudflat habitat could not be fully and accurately established with this technology.

A surprising finding of this study was the visibility of biofilm (a "slime" layer that is mixture of algae, bacteria, organic matter and sediment bound up in a gelatinous mixture on top of the mudflats that can provide food for some fish and birds feeding on the mudflat) on the surface of exposed mudflat and discernible in the satellite images. Biofilm is a food source for wildlife that very little is known about and future investigations could provide valuable insights into San Francisco Bay food webs.

As part of mapping bathymetry (the underwater equivalent to topography) in the Alviso area, Amy Foxgrover and Bruce Jaffe from USGS (Foxgrover and others, 2014) mapped a small portion of the mudflat area off Pond A6 (which was breached in December 2010) from early 2010 to late 2013. That data showed that the mudflat area off Pond A6 has been slightly depositional, increasing elevation by approximately 4-6 inches between late 2010 and November 2013. Brian Fulfrost of San Francisco Bay Bird Observatory and Kristin Byrd of the USGS have begun to investigate other techniques for mapping mudflat habitat and evaluating changes that might be due to restoration actions (Fulfrost and others, 2015a, 2015b). This work could be continued in Phase 2 to establish baseline mudflat habitats, and evaluate changes to the extent and quality of the mudflat habitat with restoration.

All of the above studies indicate that currently there is sufficient sediment to restore marshes and maintain mudflat habitat. Therefore, currently there is a positive trajectory for there to be sufficient sediment to support marsh restoration and maintain existing habitat. However, there are also data showing a decreased sediment supply into San Francisco Bay, and future sea-level rise projections suggest that there will be additional sediment demand for maintenance of marshes and mudflats. Therefore, managers have begun measures to bring in additional upland fill material and investigate the potential for beneficial reuse of dredged sediments (Valoppi and others, 2013). 


\begin{tabular}{|l|l|l|}
\hline & $\begin{array}{l}\text { Key Uncertainty: Is there sufficient sediment in the South Bay to support marsh } \\
\text { development without causing unacceptable impacts to existing habitats? }\end{array}$ & Score \\
\hline 1 & Is current vegetated marsh maintained or increased? & $\begin{array}{l}\text { Will the sediment accretion rate in restored tidal areas be adequate to create and support } \\
\text { emergent tidal habitat ecosystems within the projected 50-year timeframe? }\end{array}$ \\
\hline 3 & \begin{tabular}{l} 
Will sediment movement into restored tidal areas significantly decrease mudflat habitat? \\
\hline
\end{tabular} \\
\hline
\end{tabular}

\section{Management Responses to Phase 1 Studies}

- Managers and researchers are working together in a Mudflat Working Group and the San Francisco Bay Joint Venture to explore cost-effective methods for mapping the extent and quality of mudflat habitat.

\section{Needed Phase 2 Studies for Sediment Dynamics}

- Continued study is needed to evaluate the amount of sediment entering far South Bay and the sediment accumulation in breached ponds of Eden Landing Complex and future breaches at Ravenswood Complex as the spatial variability in sediment accumulation rates is unknown.

- Studies are needed in Phase 2 to understand the extent of mudflat habitat, to develop cost-effective and accurate methods to map baseline conditions and track future changes in mudflats, and to determine how restoration actions may affect the quantity or quality of that habitat.

○ Studies are needed to map the extent of biofilm, to understand its importance to shorebird foraging, and to learn how restoration actions might alter biofilm. 


\section{Bird Use of Changing Habitats}

In addition to restoring tidal marsh, the Project must also provide for birds that use the managed ponds remaining after some ponds are breached for tidal marsh restoration. A key focus of research during Phase 1 has been how to enhance and manage pond habitat to support a greater number of birds in fewer ponds so that more ponds can be restored to tidal marsh. About 93 species of breeding, wintering, and migratory birds use the managed pond habitat.

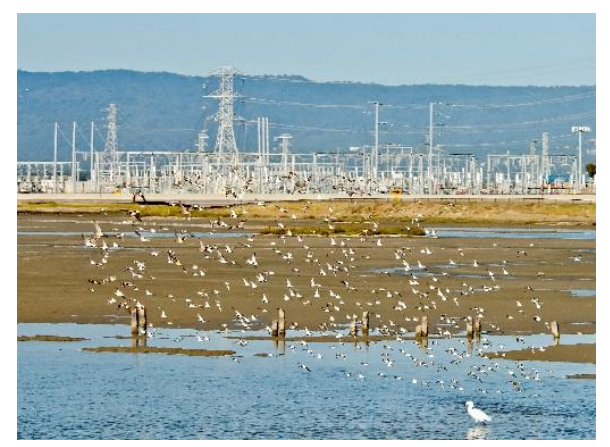

Waterbird use of shallow water areas at Pond SF2. Photograph by Pelican Media.

A number of studies have been undertaken at restoration sites that have been designed to increase bird use of managed ponds. These include:

- Bird Island Experiment: Ponds designed with islands for breeding and feeding birds (Ponds A16, SF2, E12, E13);

- Social Attraction Experiment: Using bird decoys and calls to attract nesting birds that like to breed in groups, such as terns (Ponds SF2 and A16);

- Habitat Diversity Experiment: Ponds built with varying topography and salinities designed to increase species diversity by creating habitat diversity for bird use (Ponds E12/E13);

- Multi-species Management Experiment: Ponds that evaluate timing of flood-up to provide habitat for different bird species during different seasons (Ponds E6A/E6B/E8); and

- Western Snowy Plover (Charadrius alexandrinus nivosus) Habitat Enhancement:

Experimental placement of oyster shells to evaluate effectiveness as camouflage for plover nests and chicks (Pond E14).

Studies by Josh Ackerman and Alex Hartman of the USGS on the Bird Island Experiment ponds developed an "island recipe" of the optimal size, shape, and number of islands per pond for breeding birds (Ackerman and others, 2014; Hartman and others, 2013, 2015; Valoppi and others, written commun., 2014). Researchers found it was better to have three to five islands per pond in several ponds rather than a large number of islands in just one pond. Long, skinny islands that are away from levees, are less than 5 acres in size, and have areas between 1.5 to 3 feet above the water line, are optimal for nesting birds. This recipe will be useful to managers in the design and construction of islands in other ponds to increase breeding bird habitat and productivity. 
The Bird Island Experimental islands at Ponds SF2 and A16 have had little use by breeding birds, and breeding Forester's terns (Sterna forsteri) and American avocets (Recurvirostra americana) have moved from ponds undergoing restoration and management actions, thus triggering management action per the AMP. With consultation with the Pond Management Working Group, social attraction was determined to be a viable management action. In order to increase the use of the islands in those ponds, Social Attraction Experiments were set up in 2015 by Josh Ackerman and Alex Hartman in collaboration with the U.S. Army Corps of Engineers, as a mitigation project for impacts on Caspian terns (Hydroprogne caspia) in the Pacific Northwest (Hartman and others, 2016). Social attraction consists of setting up decoys of Caspian terns, along with a solar-powered loudspeaker to emit tern calls, on a few of the islands at Ponds SF2 and A16. The idea is that real Caspian terns would be attracted to the decoys and calls and then nest on those islands. Decoys and bird calls were also set up on one island at each of those ponds for snowy plovers. In the first year, Caspian terns at the islands with decoys created 224 nests, resulting in a total of about 174 tern chicks fledged. This was unexpected, considering that very few Caspian terns have nested with the Project area in the past century. Snowy plovers were not attracted to the decoys/calls.

Other studies conducted by Stacy Moskal of the USGS on Pond SF2 focused on wintering and migratory bird use, and found that shorebirds often congregated on shallow mounds of dirt unintentionally created by earth-moving equipment (Moskal and others, 2015). Based on this observation, in another set of ponds (E12/E13), a Habitat Diversity Experiment was created by building topographic diversity that varied water depths within the ponds (De La Cruz and others, written commun., 2016).

In this design, a series of shallow channels snake through the pond bottom, alongside shallow dirt mounds - both constructed to mimic the terrain favored by the shorebirds. These ponds were also designed to carry low, medium, and high salinity water in a series of mini "salt ponds." By creating habitat diversity through variation in water depth and salinity, managers hope to increase the species diversity in these ponds. Studies in these ponds are evaluating bird use and invertebrate prey at varying levels of salinity, the bird use of the shallow mounds for foraging and roosting, and bird use of islands as nesting habitat (Takekawa and others, 2013; Ackerman and others, 2014; Washburn and others, 2015). 


\section{Key Uncertainty}

Can the existing number and diversity of migratory and breeding shorebirds and waterfowl be supported in a changing (reduced salt pond) habitat area?

Question 1. Will the habitat value and carrying capacity of South Bay for nesting and foraging migratory and resident birds be maintained or improved relative to current conditions?

Question 2. Will shallowly flooded ponds or ponds constructed with islands or furrows provide breeding habitat to support sustainable densities of snowy plovers while providing foraging and roosting habitat for migratory shorebirds?

Question 3. Will ponds reconfigured and managed to provide target water and salinity levels significantly increase the prey base for, and pond use by waterfowl, shorebirds and phalaropes/grebes compared to existing ponds not managed in this manner?

Question 4. To what extent will the creation of large isolated islands in reconfigured ponds maintain numbers (and reproductive success) of terns and other nesting birds in the South Bay, while increasing densities of foraging birds over the long term compared to ponds not managed in this manner?

Question 5. Will pond and panne habitats in restoring tidal habitats provide habitat for significant numbers of foraging and roosting shorebirds and waterfowl over the long term?

In ponds E6A, E6B, and E8, a multi-species management experiment that created dry habitat for the threatened western snowy plover during summer nesting and wet foraging habitat for diving ducks during the winter is being studied by Susan De La Cruz of the USGS and Karine Tokatlian of the San Francisco Bay Bird Observatory (De La Cruze and others, 2015). Research will evaluate plover nesting success in the spring and summer, how a seasonal drying and wetting regime influences benthic invertebrate prey species for diving ducks in fall and winter, and also evaluate the physical and landscape characteristics of ponds that enhance diving duck abundance and foraging behavior. Preliminary results from the plover studies indicate that ponds with a dry pond bottom and internal water channels resulted in higher plover nesting success. Preliminary results for diving ducks indicate that there were fewer lesser scaup (a species of diving duck, Aythya affinis) (observed in seasonally dry ponds compared to unmanaged ponds, while ruddy duck (Oxyura jamaicensis) numbers were similar between pond types. Diving duck behavior was similar between the seasonally dry and unmanaged ponds.

A Snowy Plover Habitat Enhancement Study is being conducted on Pond E14 by Karine Tokatlian and Caitlin Robinson-Nilsen of the San Francisco Bay Bird Observatory. Oyster shells were placed on portions of the dry pond bottom and then plover nesting success was evaluated (Tokatlian and others, 2016). Plovers have a number of known predators, such as California gulls (Larus californicus), common ravens (Corvus corax), and northern harriers (Circus cyaneus), red-tailed hawk (Buteo jamaicensis), which decrease nest success (Tokatlian, 2015; Tokatlian and others, 2015). By adding oyster shells to the pond surface, the shells provide camouflage for eggs and chicks and may help reduce 
the amount of predation. First year results indicated 98 plover nests in this pond, and shell treatment increased breeding bird numbers, nesting density, and apparent chick fledge rates compared to previous years. However, statistically there was no significant effect on nest survival or chick behavior in the shell areas, perhaps because the small sample size was not sufficient to detect a change. Continued monitoring of shell enhancement on plover nesting is needed, as is continued monitoring of plover nesting (Pearl and others, 2016).

In addition to the focused studies noted above, USGS and the San Francisco Bay Bird Observatory have monitored bird use of all ponds during high tide every 4-6 weeks since 2003 (Washburn and others, 2015; De La Cruz and others, 2016). Basic habitat characteristics of the ponds, such as salinity and water depth and other features, were also recorded. This allowed for an extensive analysis by Susan De La Cruz of the USGS of the pond characteristics favored by nine bird guildsdabbling ducks, diving ducks, eared grebes, fish-eaters, gulls, herons and egrets, medium shorebirds, small shorebirds, and terns. During the period surveyed, 93 species of birds were observed, with diving and dabbling ducks (35 percent), small and medium shorebirds (49 percent), and gulls (11 percent) being the most abundant guilds. Peak abundances were observed in winter months. Total winter waterbird abundance increased non-linearly over the study period, more than doubling from 98,151 birds in 2002 to 235,936 in 2014 (fig. 6). Pond depth and salinity were key variables related to bird distributions across the ponds; this analysis can be used by managers to refine pond operations in order to increase bird use.

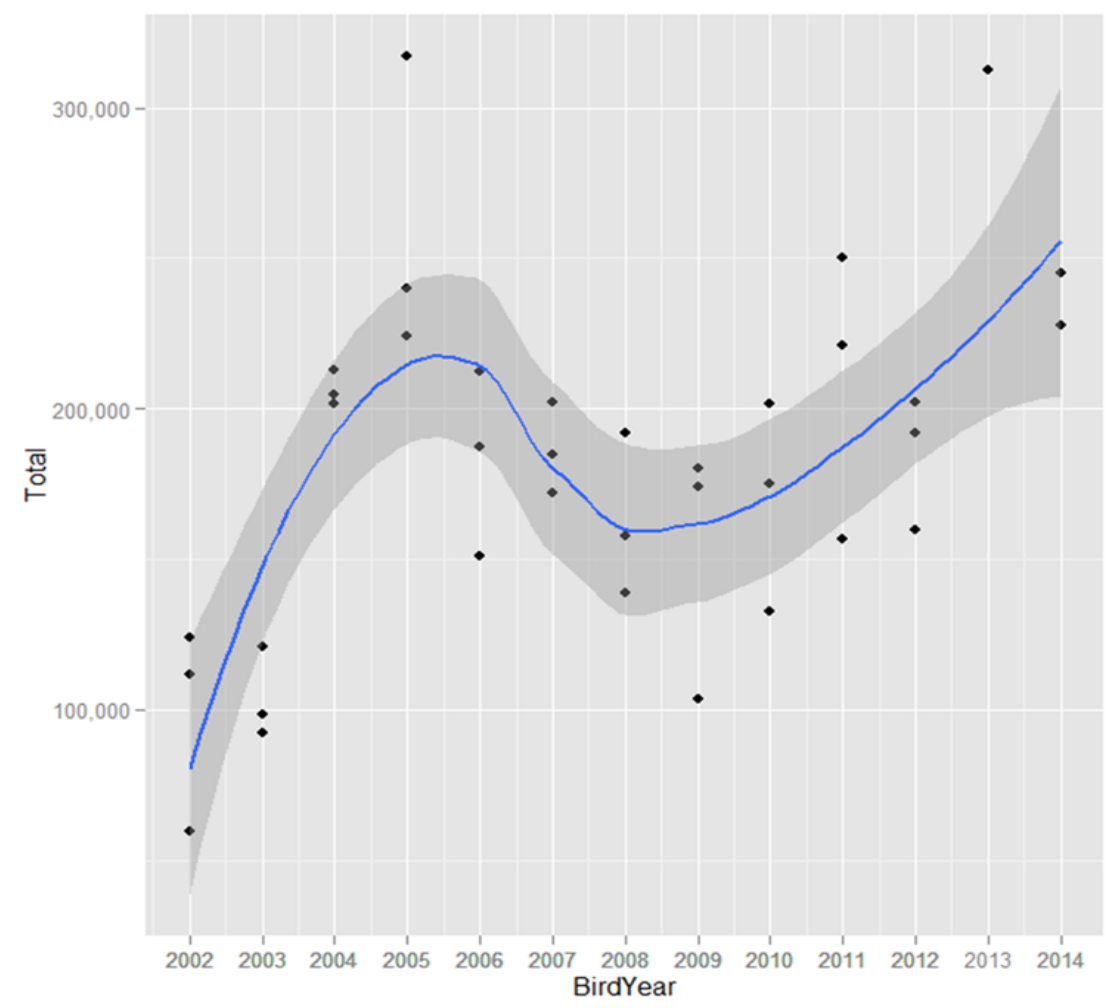

Figure 6: Graph showing overall South Bay Wintering Bird Abundance. The blue solid line is the mean number of birds for each year and the gray bands represent the 95-percent confidence limits around the mean. Graphic provided by Susan De La Cruz, U.S. Geological Survey. 


\begin{tabular}{|l|l|l|}
\hline & $\begin{array}{l}\text { Key Uncertainties: Can the existing number and diversity of migratory and breeding } \\
\text { shorebirds and waterfowl in the Project area be supported with reductions in salt pond } \\
\text { acreage? }\end{array}$ & Score \\
\hline 1 & Is the number of diving ducks maintained? & \\
\hline 2 & Is the number of ruddy ducks maintained? & \\
\hline 3 & Will managed ponds provide foraging and roosting habitat for migratory shorebirds? & \\
\hline 4 & $\begin{array}{l}\text { Will managed ponds provide breeding habitat to support sustainable densities of snowy } \\
\text { plovers? }\end{array}$ & \\
\hline 5 & $\begin{array}{l}\text { To what extent will the creation of large isolated pond islands maintain numbers and } \\
\text { reproductive success of terns, avocet, and stilts? }\end{array}$ & \\
\hline 6 & $\begin{array}{l}\text { Will reconfigured and managed ponds significantly increase the prey base for, and pond } \\
\text { use by, waterfowl, shorebirds, and phalaropes/grebes? }\end{array}$ & \\
\hline 7 & \begin{tabular}{l} 
Is the number of California least terns in the Project area maintained? \\
\hline
\end{tabular} \\
\hline
\end{tabular}

\section{Management Responses to Phase 1 Studies}

- Managers reworked the surface of the islands at Pond SF2 in response to crack development after chicks were lost in the first year after construction.

- Managers worked with engineers to redesign how islands were constructed at Ponds A16 and E12/E13 in order to minimize cracking.

- A pilot project to investigate surface treatments for islands was conducted at Ponds E12/13 prior to construction of the remaining islands.

- Mounds and shallow water features for birds were added to Ponds E12/13 design.

- The "island recipe" for constructing islands to maximize use by breeding birds is being incorporated into Phase 2 actions.

- A Pond Management Working Group, comprised of managers and researchers, meets regularly to evaluate bird survey data and make recommendations for changes to managed pond operation for optimization of bird use. 


\section{Needed Phase 2 Studies for Bird Use of Changing Habitats}

- Continue the high tide bird surveys on all ponds to understand bird-habitat linkages, long-term impacts of conversion of ponds to marsh, and develop optimal or target salinity and water levels for bird guilds and species.

- Study food availability in ponds to continue understanding the carrying capacity of the ponds, especially for diving ducks.

- Study how to maximize islands for shorebird foraging and roosting.

- Further study of California gull predation on shorebird and tern eggs and chicks as ponds are restored; GPS mark gulls to evaluate habitat use and use of landfills; understand if gull population increases as a result of local reproduction or immigration; identify gull diet to understand percentage from landfills.

- Continue social attraction studies on newly constructed islands for terns.

- Continue enhancing islands and creating islands for nesting habitat.

- Continue studying breeding bird nest abundance and nest success in the Project area to understand long term trends.

- Conduct a population count of breeding avocets, stilts, and Forster's terns in the entire South Bay to determine if populations have declined, especially for avocets whose breeding population appears to have declined.

- Continue habitat enhancement and predator management of plover nesting areas and study their effectiveness.

○ Conduct additional snowy plover studies to track brood movement and estimate fledging rates.

○ Understand snowy plover carrying capacity or density limits; understand use of foraging on transitional mudflat habitat; understand movement and migration out of historical areas from habitat restoration.

- Explore the use of unmanned aerial vehicles for monitoring as well as their possible impacts to wildlife.

- Monitor bird use of newly restored areas as they change from mudflats to vegetated marsh, including the use of panne habitat.

- Continue understanding carrying capacity of mudflat habitat and biofilm for shorebirds. 


\section{Mercury}

Mercury, a potent neurological and reproductive toxin, is an unfortunate legacy of the California gold rush in much of the San Francisco Estuary and its watershed. Mined from the Coast Range and then used in the Sierra Nevada mines to extract gold, extensive amounts of mercury continues to wash out of these former mining areas and collect in the sediments of San Francisco Estuary. One of the largest mercury mines in North America, the New Almaden Mine, released contaminated material into the surrounding area that eventually washed down into the Guadalupe River, contaminating the sediments. The Guadalupe River drains into Alviso Slough, in the center of the Alviso Pond Complex. As a result, the ponds adjacent to Alviso Slough, including Pond A8, have extensive mercury deposits, and prior studies had found high concentrations of mercury in fish and bird eggs in Pond A8. There was concern that fully restoring Pond A8 would increase the amount of mercury that was in the bioavailable form - methylmercury (MeHg)-the more toxic form of mercury that is readily taken up into wildlife food webs. It is the MeHg form that bioaccumulates through food webs, not the inorganic mercury. Complex biogeochemical processes operate to convert the inorganic mercury to $\mathrm{MeHg}$, so inorganic mercury is not a good indicator of the amount of $\mathrm{MeHg}$ present.

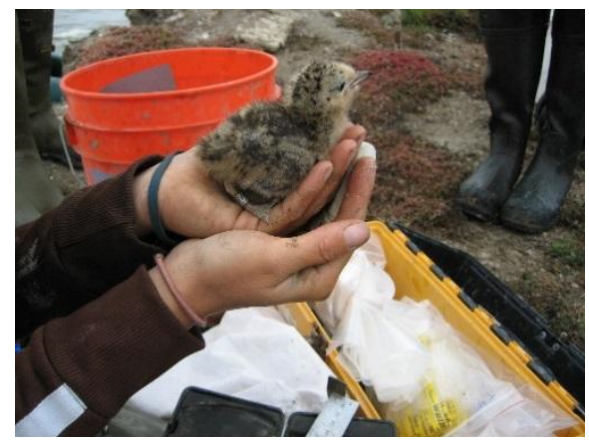

Forster's tern chick being banded for nest success study for mercury research. Photograph by Laura Valoppi, U.S. Geological Survey.

\section{Key Uncertainty}

Will mercury be mobilized into the food web of the South Bay and beyond at a greater rate than prior to restoration?

Question 1. Will tidal habitat restoration and associated channel scour increase $\mathrm{MeHg}$ concentrations in marsh and bay-associated sentinel species?

Question 2. Will pond management increase MeHg concentrations in ponds and pondassociated sentinel species? 
To address these concerns at Pond A8, managers installed a 40-foot water control structure, a structure with eight gates (each 5 feet wide) that each can be opened and closed independently, to control the flow of water through the pond. This will allow researchers to study bioaccumulation and movement of mercury over several years (fig. 7). Construction occurred within Ponds A5, A7, and A8 to breach internal levees. Once opened, this would create one large 1,400 acre pond consisting of Ponds A5, A7, and A8 (renamed as Pond A8). Construction actions also included excavation of a pilot channel to connect the Pond A8 notch to Alviso Slough. In addition to concerns about mercury inside the Pond A8, there was also concern that mercury buried in sediment at the bottom of Alviso Slough would be remobilized when the opening of the gates increased water flows in the slough and scoured out bottom sediments. In an independent action in December 2010, Pond A6 was breached farther downstream from Pond A8, near the mouth of Alviso Slough and Coyote Creek. This occurred prior to the completion of Pond A8 restoration actions (fig. 8). Scour from this breach event could also influence the mobilization of $\mathrm{MeHg}$ in Alviso Slough. Additionally, as a requirement by the National Marine Fisheries Service (NMFS), the gates needed to be closed between December 1 and May 31 so as not to allow migrating steelhead to enter Pond A8 and become trapped.

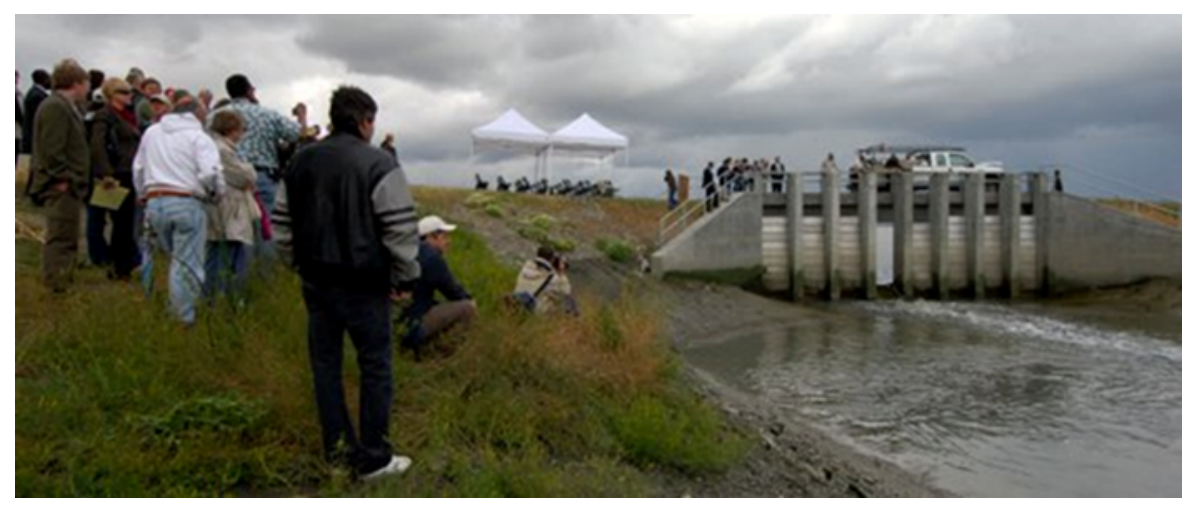

Figure 7. Photograph showing Pond A8, which is 40 feet wide with eight gates that can be independently opened or closed, South Bay Salt Pond Restoration Project, California. Photograph by Pelican Media. 


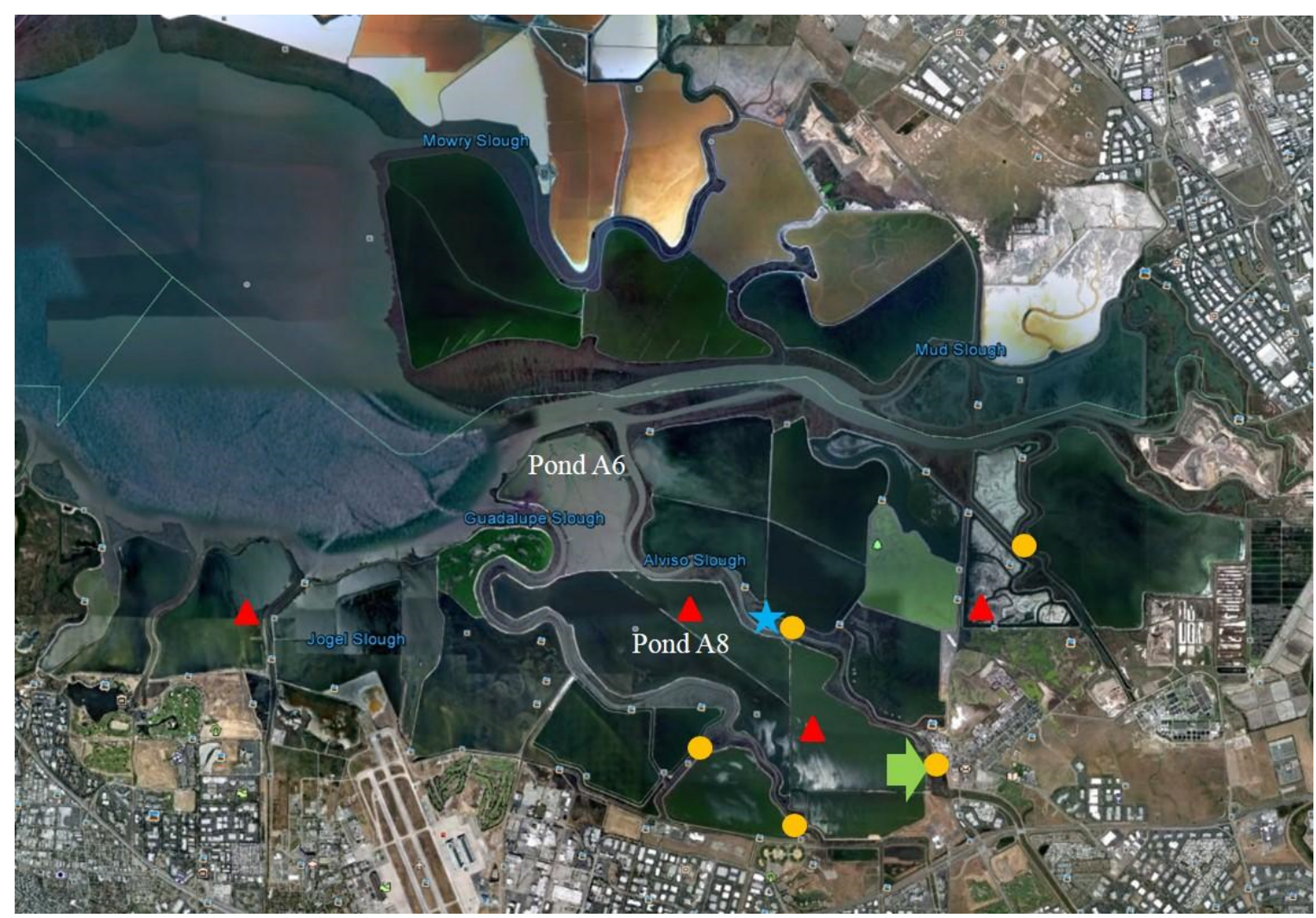

Figure 8. Map showing Pond A8, Alviso Slough, and vicinity, South Bay Salt Pond Restoration Project, California. Green arrow indicates where the notch with gates is located; red triangles indicate where bird eggs were collected; orange circles indicate where slough fish and water samples were collected; blue star indicates where sediment flux station, water quality, and mercury water samples were collected. 
To study the effect of opening the Pond A8 gates, in 2010 baseline mercury conditions prior to opening the gates were documented by a team of researchers. Mercury in bird eggs (Forster's tern and American avocet) and fish inside the pond (longjaw mudsucker [Gillichthys mirabilis] and three-spined stickleback [Gasterosteus aculeatus]) were measured by Josh Ackerman of the USGS (Ackerman and others, 2014, 2015). Fish outside the pond in Alviso Slough (Mississippi silverside [Menidia beryllina] and three-spined stickleback) were collected and analyzed for mercury by Darrel Slotton of University of California, Davis. Mercury in water and sediment in the pond and slough were collected and analyzed by Mark Marvin-DiPasquale of the USGS (fig. 8) (Slotton, 2017). Once the gates were opened, increased flows may result in increased scour in Alviso Slough. To evaluate sediment scour and the remobilization of buried mercury in the sediments of Alviso Slough, bathymetric surveys of the slough from Pond A8 to the mouth of the slough were conducted by Bruce Jaffe of the USGS (Foxgrover, Finlayson, and others, 2015; Foxgrover, Jaffe, and others, 2015; Jaffe and others, 2015). A detailed map of where the slough sediment was eroded or deposited was necessary to be able to estimate how much mercury would be released from Alviso Slough sediments. Mark Marvin-DiPasquale, of the USGS took deep sediment cores at several locations along the slough, and identified the amount of mercury in each layer of the core (Marvin-DiPasquale and Cox, 2017). These mercury cores established the concentration of mercury at depth in the sediments along Alviso Slough.

On June 1, 2011, one of the eight gates ( 5 feet out of 40 feet wide gate) in Pond A8 was opened, and the effects of opening the pond to muted tidal flows were studied. The flows were termed muted to reflect that the full tidal volume of water could not flow through the gate. The results from the first year studies indicated that mercury increased significantly in fish in Pond A8 likely from the construction activities inside Pond A8, then decreased after the gate opening. The terns feeding on the fish inside Pond A8 laid eggs with substantially higher (69 percent) mercury concentrations after the construction activities than before, and higher than in nearby reference areas. However, another bird species, the avocet, had little change in mercury concentrations in their eggs compared to before construction and compared to nearby reference areas. The management team was encouraged that Pond A8 fish mercury concentrations decreased after the June 1 notch opening. Although mercury concentrations in fish from the slough initially increased in the first few months after the gate opening, by October 2011, concentrations decreased to levels seen before the restoration activities. Thus for both Pond A8 fish and slough fish, the decrease in mercury concentrations happened within a few months of opening the gate at the notch. In contrast, tern eggs remained high in mercury because eggs represent an aggregate of the mercury in the environment ingested by the adult bird within a few weeks before the eggs were laid, and thus did not decrease after the gates were opened. The initial increase in mercury seen in tern eggs and fish may have been related to the construction activities within or just outside Pond A8, where a perturbation in a system can temporarily increase mercury in biota. The decrease in fish mercury concentrations after the gate opening was consistent with similar decreases in total mercury concentrations in surface water and MeHg concentrations in Pond A8 and Alviso Slough. In 2012, prior to the above results being available and based on a previously approved operation plan, managers opened three gates to the Pond A8 structure, for a total of 15 feet open to tidal flow. This action tripled the volume of water flowing through the notch (fig. 9). 


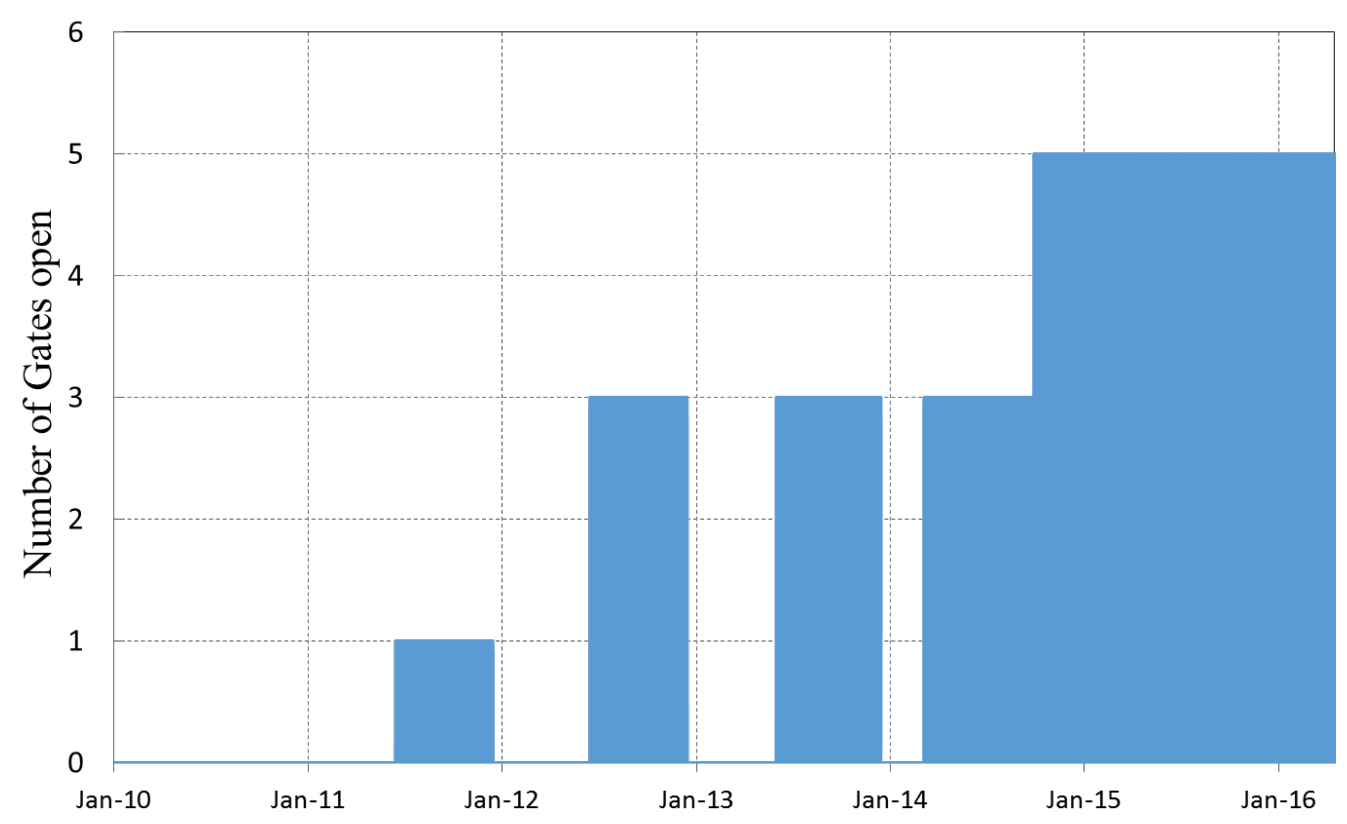

Figure 9. Graph showing history of Pond A8 gate opening and closing, South Bay Salt Pond Restoration Project, California. Base graphic courtesy of Matt Brennan, Environmental Science Associates .

Project funding did not allow for additional collection of surface water, fish, or bird egg samples until 2013, when the Project received a grant from the U.S. Environmental Protection Agency. The 2013 study results indicated that mercury concentrations in tern eggs decreased 59 percent between 2011 and 2013 at restored ponds, compared to a decrease of 23 percent between years at reference ponds. The end result of this 3-year comparison was that tern egg mercury concentrations decreased between 2010 and 2013 by 31 percent at both restored and reference ponds (fig. 10). Despite the substantial increase in mercury concentrations in tern eggs immediately after Pond A8 was opened in 2011, mercury concentrations in tern eggs in the restored ponds by 2013 were at concentrations similar to what would have been expected without the restoration actions having occurred. Furthermore, by 2013, results from the collection of slough fish saw no major increases in mercury concentrations compared to the period prior to the opening of the Pond A8 notch to triple its previous volume. Bathymetric survey data from 2010 to November 2013 showed continued erosion and deposition occurring in various sections of Alviso Slough, with a net scour of about 6 inches throughout the slough. Mercury remobilization occurred mostly near the Pond A6 breaches, and to a lesser extent near the Pond A8 notch. It is estimated that, between December 2010 and November 2013, about 21-24 kilograms of total mercury had been remobilized in Alviso Slough with up to three gates open (15 feet), compared to a previously predicted amount of about 66 kilograms of total mercury remobilized with four gates open (20 feet). The latter estimate did not take into consideration the effect the Pond A6 breaches would have on scour of Alviso Slough near the Pond A6 breaches, and thus the remobilization of mercury in that segment of Alviso Slough. 


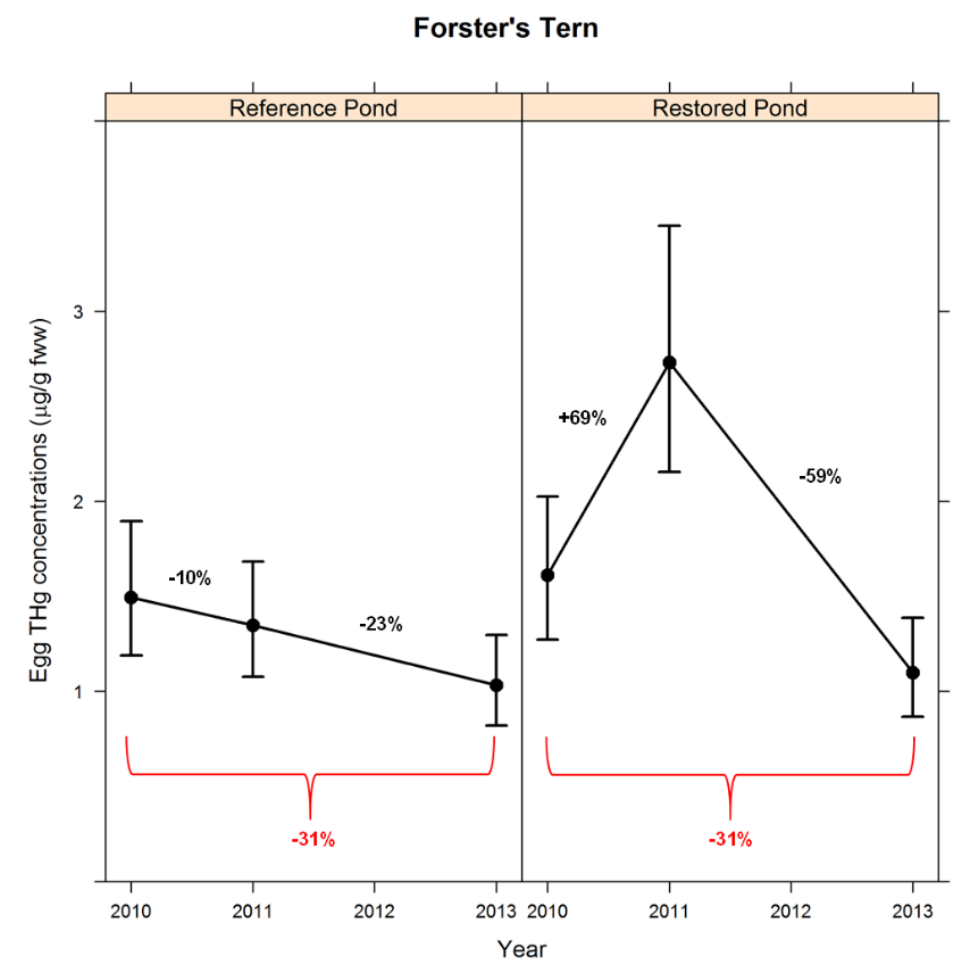

Figure 10. Graph showing mercury concentrations in Forster's tern eggs, South Bay Salt Pond Restoration Project, California, 2010-13. Graphic courtesy of Josh Ackerman, U.S. Geological Survey.

From 2010 to 2014, under National Marine Fisheries Service requirements designed to prevent migrating young steelhead (smolts) from accidentally being carried by water flow into the pond and trapped, Pond A8 gates could be open only between June 1 and December 1 of each year, the smolt migratory period. Based on the data collected up to that period, as well as other reports in the published mercury literature, researchers concluded that opening and closing the notch every 6 months constituted a significant repeated perturbation such that $\mathrm{MeHg}$ production would be exacerbated, particularly in Pond A8. They hypothesized that keeping the notch open year round would be an option with respect to minimizing $\mathrm{MeHg}$ production and might also benefit nesting birds which require stable water levels during the nesting season. The second best option would be to open the notch earlier so that the bird nests are not flooded, but to have flow-through so that the conditions believed to enhance mercury methylation are minimized. The Project worked with the National Marine Fisheries Service to allow a 1year operational change, with Pond A8 gates open from March 1, 2014, until December 2015. This allowed managers and researchers to investigate the effects on mercury bioaccumulation, remobilization, and water quality when opening the gates earlier in the year or all year round.

Based on the results of mercury studies conducted yearly from 2013 onward, in early March 2014, three gates were opened (3 months earlier than in previous years), and on September 29, 2014, two additional gates were opened for a total of five out of eight gates being opened to muted tidal flows into Pond A8 (fig. 9). The five gates have remained open since then, including for the first time remaining open past December 1. During 2014 and 2015, researchers studied the effects of leaving the gates open during the winter months and keeping the gates open all year. The results showed that mercury concentrations in tern and avocet eggs (fig. 11), and slough fish fluctuated year to year, but 
these fluctuations were consistent with nearby reference locations. Therefore, the changes in mercury concentrations could not be attributed to the opening of the gates early in 2014, or to leaving the gates open throughout the winter of 2014-15. Sediment remobilization in Alviso Slough continued throughout 2014 and 2015, with a pattern of erosion during the fall and winter months, and deposition during the spring and summer months. From December 2010 to October 2015, about 35-39 $\mathrm{kg}$ total Hg was remobilized over the entire length of slough. About 64 percent was from the mid-slough region down to the mouth of the slough. About one-third of the total was immediately near the Pond A6 breaches. The least Hg remobilization was near the Pond A8 notch (5-10 percent of total). This amount of mercury remobilized was lower than what had been previously modeled, which indicated 66-125 kg would be remobilized from opening the Pond A8 notch, without taking into account the breaching of Pond A6 levees (Fergosa, 2013; Marvin-DiPasquale, 2013).
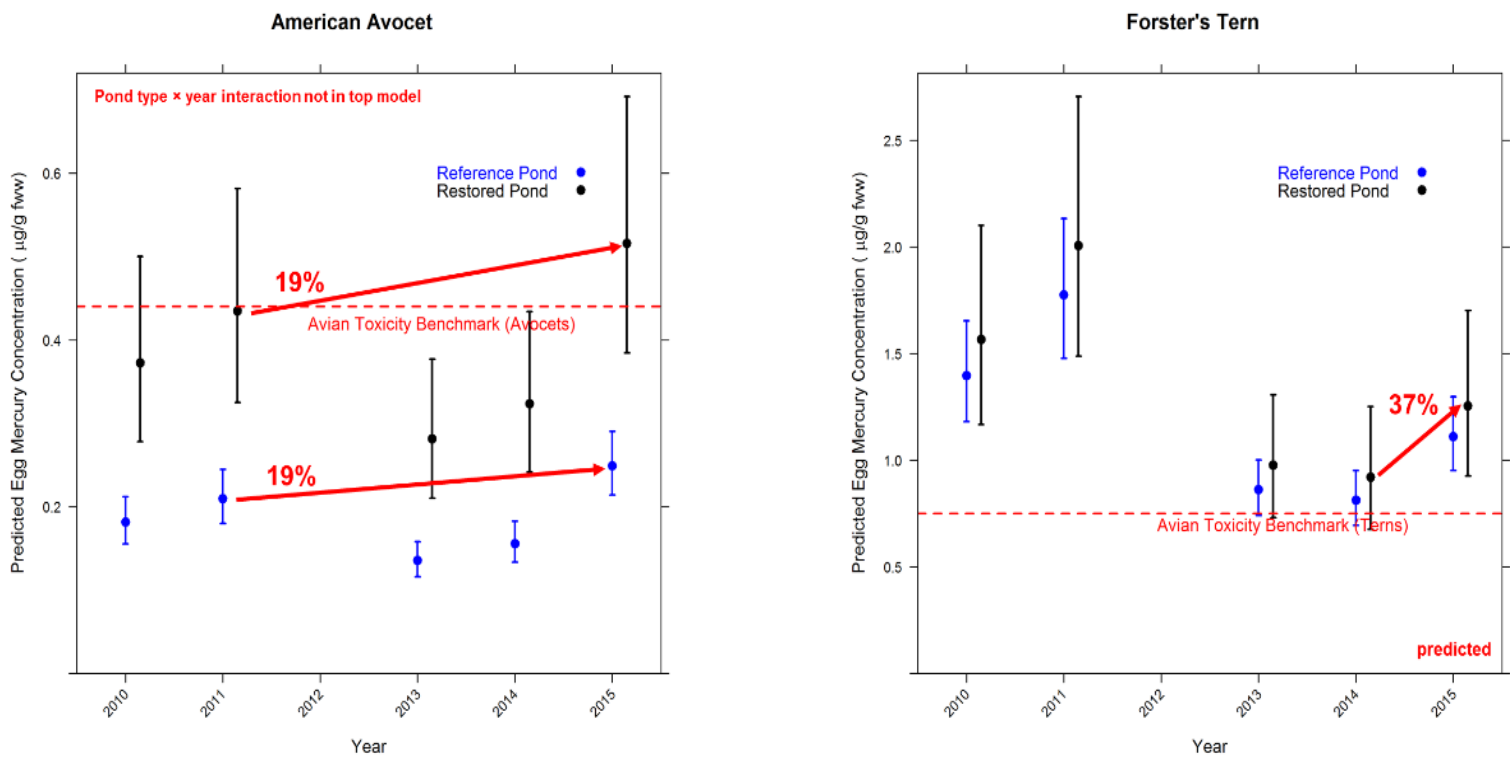

Figure11. Graphs showing mercury concentrations in Forster's Tern and American Avocet eggs after opening the Pond A8 gates, South Bay Salt Pond Restoration Project, California, 2010-15. Graphic courtesy of Josh Ackerman, U.S. Geological Survey.

Understanding the movement of sediment in Alviso Slough allows for a better understanding of the movement of mercury in the slough because much of the mercury is attached to the suspended sediment particles (although some is also dissolved in water). In order to characterize the amount of sediment moving in Alviso Slough, a sediment flux (turbidity and velocity) and water quality (temperature, salinity, and dissolved oxygen [DO]) station has been installed about midway between the Pond A8 notch and the mouth of Alviso Slough (fig. 8). Dave Schoellhamer, Greg Shellenbarger, and Maureen Downing-Kunz of USGS have studied the sediment movement at this location since fall 2010 (Downing-Kunz and others, 2017). They found that net sediment movement in the water (suspended sediment) is generally landward, or upstream, except during rainfall events. Peak suspended-sediment concentrations are associated with the movement of the denser salt water as it moved along the bottom of the slough past the fixed monitoring station during flood tides. The data indicate that during spring tides, peak suspended-sediment concentrations occur on the flood (incoming) tide cycle, while during neap tides, peak suspended-sediment concentrations occur on the ebb 
(outgoing) tide cycle. Neap tide concentration peaks are about three times lower than spring tide peaks. Therefore, movement of remobilized mercury attached to the sediment would also follow this pattern, and this information is useful for understanding whether the mercury-laden sediment is moving out toward the bay, or upstream and depositing in Pond A8 or other areas upstream. Preliminary waterquality data also indicates that opening of the gates increases the salinity levels and results in less fluctuation in salinity levels in Alviso Slough water.

To better understand the relationship between the suspended sediment and the mercury attached to the sediment, a study focusing on mercury associated with sediment particles was conducted in 2012 13 by Mark Marvin-DiPasquale, in conjunction with the mid-Alviso Slough station noted above (Ackerman and others, 2015). Water samples were collected at regular intervals over a 25-hour period during the four seasons plus during the first large rain event. Mercury concentrations were characterized as "total mercury," which is the sum of all forms of inorganic and organic mercury. MeHg is another form of mercury characterized because it is the most bioavailable form. Mercury that is dissolved in water, as well as mercury that is attached to sediments (particulate mercury) is also characterized. Results from this study indicate that suspended particulate total mercury concentrations responded strongly to tidal cycles, with mercury concentrations generally increasing during ebb tide and decreasing during flood tide. The December "first large rainfall" event exhibited the least amount of mercury concentration variability. The portioning of total mercury between the particulate and dissolved phases also changed throughout the tidal cycle, with proportionally more total mercury found with suspended particles during the low tide phases. During the winter/spring, the composition of the suspended particle portion was dominated by algae during flood tides. This suggests an enhanced degree of mercury bioavailability during the flood tide phase (to the extent that particle-bound mercury is associated with algae instead of inorganic particles). For example, if the particles that the mercury is bound to are algae, then an organism that eats algae would also take up the mercury, thus allowing mercury to move up the food chain. However, if the particle was sediment, it is much less likely to be eaten and taken up by other organisms, so the mercury is less likely to move up the food chain. This study demonstrates that careful attention to timing in sample collection is important, and suggests that there is an interplay of tidal and chemical processes that control mercury-laden suspended-sediment movement and bioaccumulation in Alviso Slough.

\begin{tabular}{|c|l|l|}
\hline & $\begin{array}{l}\text { Key Uncertainty: Will mercury be mobilized into the food web of the South Bay and } \\
\text { beyond at a greater rate than prior to restoration? }\end{array}$ & Score \\
\hline 1a & $\begin{array}{l}\text { Will pond management increase MeHg concentrations in ponds and pond-associated } \\
\text { sentinel species during or immediately after construction? }\end{array}$ & $\begin{array}{l}\text { Will pond management increase MeHg concentrations in ponds and pond-associated } \\
\text { sentinel species post-construction? }\end{array}$ \\
\hline 1b & $\begin{array}{l}\text { Will tidal habitat restoration and associated channel scour increase MeHg } \\
\text { concentrations in marsh, sloughs, and Bay-associated sentinel species? }\end{array}$ & \\
\hline
\end{tabular}

\begin{tabular}{|l|l|l|l|l|l}
\hline Meets/exceeds expectations & Uncertain, trending positive & Uncertain & Uncertain, trending negative & Not meeting expectations \\
\hline
\end{tabular} 


\section{Management Responses to Phase 1 Studies}

- A Mercury Working Group comprised of managers and researchers meets regularly to discuss scientific findings, needed additional studies, and make recommendations for operation of the Pond A8 gates. Although there was an anticipated schedule for opening the gates at Pond A8, each year the decision was based on the results of the yearly mercury studies that were conducted from 2010 to 2016.

- Managers coordinate with Regulatory Agencies to present findings and obtain permission to operate Pond A8 per the Mercury Working Group recommendations.

\section{Needed Phase 2 Studies for Mercury}

○ Explore how to manage ponds to decrease $\mathrm{MeHg}$.

○ Study the effect of mercury on breeding birds such as terns, stilts, black skimmers, and snowy plovers.

- Establish a regional, long-term mercury monitoring program at set sites and with indicator species, including restored areas and managed ponds. In managed ponds, evaluate management practices that reduce mercury availability and thus decrease $\mathrm{MeHg}$ in biota.

- Study mercury in marsh species, such as the Ridgway's rail and their diet (related to environmental exposure of $\mathrm{Hg}$ ), so that concentrations of concern in a marsh could be determined. For example, collect rail prey items for mercury analysis to evaluate dietary mercury exposure in newly restored marshes and reference areas. Consider additional mercury biosentinels in marsh habitats such as salt marsh harvest mouse, bats, marsh wrens (cistothorus palustris), and song sparrows (melospiza melodia).

- Continue the assessment of Pond A8 complex (including Ponds A5 and A7) to determine how to move forward with management actions.

- Conduct a statistical analysis of existing data to identify relationships between water and fish to determine if the best indicators of mercury accumulation and movement. Evaluate the preferred biosentinels to use if funding is low-water, fish, or bird eggs? Also evaluate which fish species inside the ponds is the most informative indicator over the long term.

- Evaluate use of satellite imagery to assess mercury status in the Project (similar to recent approach taken in the Sacramento-San Joaquin River Delta).

○ Assess long-term mercury movement in sloughs and marshes; validate scour model.

O Study the accretion of sediment and mercury inside Pond A8; also evaluate mercury flux between Alviso Slough and Pond A8.

- Evaluate where the mercury that is remobilized in Alviso Slough during scour is moving to. If it is accumulating in wetlands where is it bioavailable? 


\section{Effects on Aquatic Species}

The Project expects that opening ponds to tidal flows would benefit native aquatic species and potentially create nursery grounds for native fish. Several Phase 1 studies focused on documenting fish use of newly restored areas and adjacent channels. No studies have been conducted on harbor seals (Phoca vitulina).

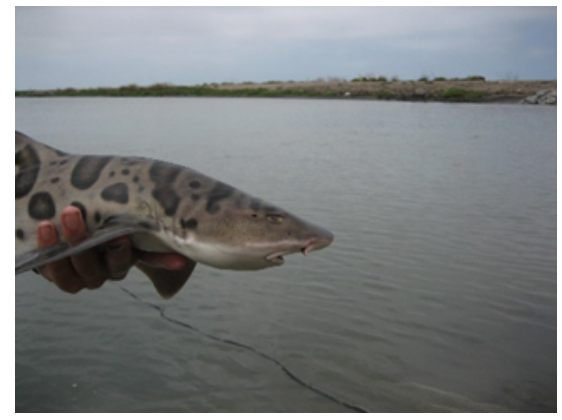

Photograph of a leopard shark at Eden Landing.

Photograph by Laura Valoppi, U.S. Geological Survey.

As mentioned in the Mercury Section above, the Project had permit requirements from the National Marine Fisheries Service (NMFS) that required closing Pond A8 from December 1 to June 1 to prevent threatened steelhead smolt from entering Pond A8 from Guadalupe River and Alviso Slough and perishing. In consultation with NMFS, Jim Hobbs of the University of California, Davis, conducted a 2 year (2013 and 2014) study on steelhead smolt outmigration from the Guadalupe River watershed in collaboration with biologists from Santa Clara Valley Water District (Hobbs and others, 2014; Hobbs, 2015). Seventy steelhead smolts were captured then tagged using a Passive Integrated Transponder (PIT) encoded with a unique identification number, and released. To detect out-migration, radio Frequency Identification (RFID) antennas were installed in the Guadalupe River downstream from the San Jose International Airport, on the three open bays on the Pond A8 notch structure, and the water control structures in Ponds A5 and A7. The PIT is much like what is used in pets for identification purposes, and the RFID antennas pick up the signal if a fish with the PIT passes by.

\section{Key Uncertainty}

Can restoration actions be configured to maximize benefits to non-avian species both onsite and in adjacent waterways?

Question 1. To what extent will increased tidal habitats increase survival, growth and reproduction of native species, especially fish and harbor seals? 
The antenna systems were installed by early March 2014, and three of the Pond A8 gates were opened early as part of this study. Of the 70 fish that were tagged, 6 fish were detected at the upstream antenna located on the Guadalupe River, or 9 percent of the tagged fish. The remaining fish that were tagged but not detected at the upstream antenna may have been missed out-migrating when the upstream antenna was down during rainfall events, or the tagged fish were eaten by predators, or the tagged fish had not migrated downstream. One fish was detected passing the upstream antenna on March 16, and then detected again at the Pond A8 antenna 9 days later, and was inferred to be exiting the notch based upon the tidal stage at the time detected. The other five tagged fish detected at the upstream antenna presumably out-migrated past the Pond A8 notch. The study was expanded the following year with biologists from the California Department of Fish and Wildlife conducting the collection of fish throughout the Santa Clara Valley watershed. This was the second year of significant drought and many sites were dry. In total, 28 fish were tagged. Antennas could not be placed in the upstream location or on the Ponds A5 and A7 intakes due to technical issues, and delays were encountered on securing antennas to all of the open gates at the Pond A8 notch. Due to drought conditions in winter 2015, flows in the Guadalupe River were extremely low, and much of the system had areas where no water flowed in the streambed for most of the winter, precluding opportunities for smolt outmigration. Steelhead studies were not conducted in 2016 due to impacts of the drought on steelhead within the watershed. Continuation of studies were planned for 2017, provided the steelhead population recovered sufficiently.

To assess the use of newly restored areas by aquatic organisms, Jim Hobbs conducted surveys in the Alviso, Eden Landing, Ravenswood, and Bair Island Complexes from July 2010 to July 2014 (Hobbs and others, 2015a, 2015b, 2015c, 2015d, 2016; Cook and others, 2016; Cook and others, written commun., 2016). The Alviso Complex, including tidal restoration Ponds A6, A17, A19, and A21, had the highest abundance of fish and macroinvertebrates as well as species richness of the Complexes studied. In the Alviso Complex, the studies found "winter-assemblages" and "summer-assemblages" of species, along with year-round residents (fig. 12). A total of 58 species of fish were identified, including 40 native species. The total catch was 90 percent native fish, with the most abundant species being: Pacific staghorn sculpin (Leptocottus armatus), three-spine stickleback, northern anchovy (Engraulis mordax), English sole (Parophrys vetulus), yellowfin goby (non-native, Acanthogobius flavimanus), Pacific herring (Clupea pallasii), and Arrow goby (Clevelandia ios). No steelhead smolts or endangered green sturgeon (Acipenser medirostris) were encountered during fish surveys. Overall, shrimp made up 61 percent of the total number of organisms counted, while fish comprised about 20 percent, clams 17 percent of the total catch, and the remaining 2 percent were worms. Grass shrimp was the most abundant species encountered during the study. The abundance and diversity of organisms was different in managed ponds. There, non-native species comprised the majority of catch (84 percent), but total catch (fish and invertebrates) was two-fold greater in managed ponds compared to full tidal restoration ponds (fig. 13, lower graphs). 


\section{Summer Assemblage}

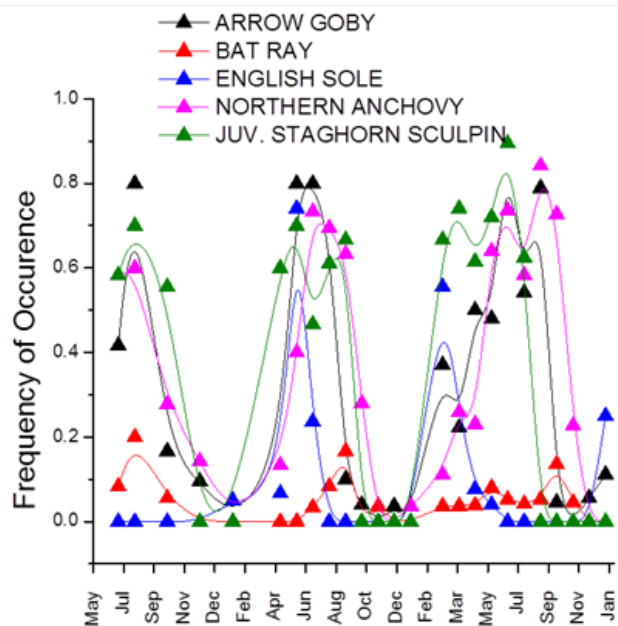

\section{Winter Assemblage}

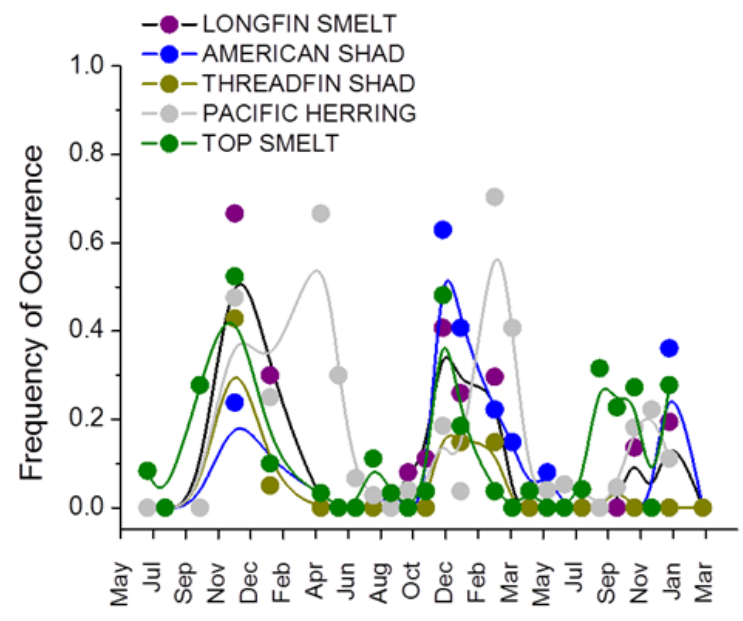

Figure 12. Graphs showing summer and winter assemblages of fish in Alviso Complex, South Bay Salt Pond Restoration Project, 2010-13. Graphic courtesy of Jon Cooks and Jim Hobbs, University of California-Davis.

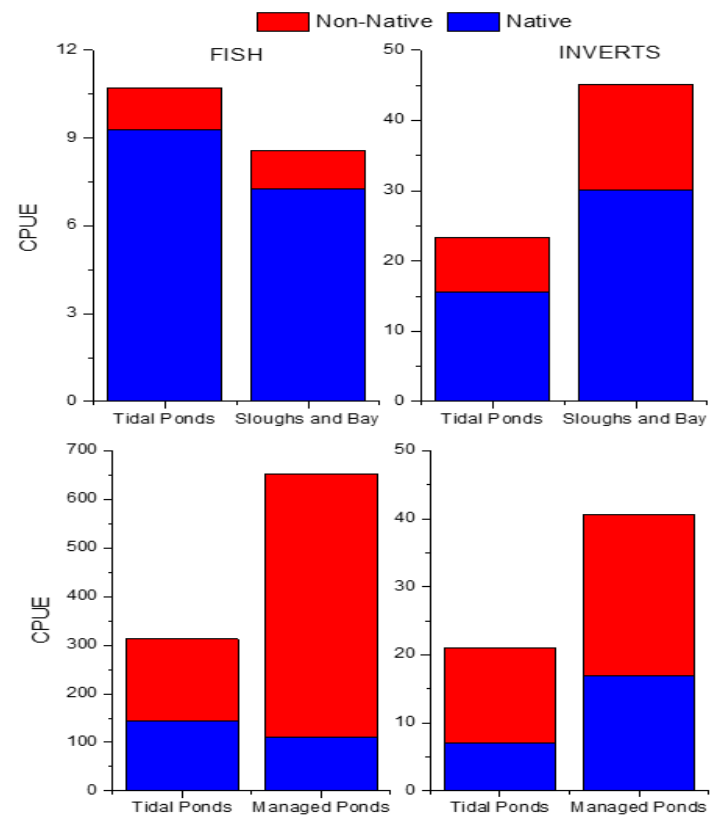

Figure 13. Graphs showing mean catch-per-unit-effort CPUE of fish and macro-invertebrates in fully tidal restoration ponds (Tidal Ponds) versus Sloughs in the Alviso Marsh and stations in Lower South Bay habitats sampled via otter trawls (upper graphs), and comparisons between Tidal Ponds and tidally muted (Managed Ponds) via beach seine (lower graphs), South Bay Salt Pond Restoration Project, California. Graphic courtesy of Jim Hobbs, University of California, Davis. 
Jim Hobbs also monitored species assemblages between the tidal restoration ponds and adjacent slough habitats to determine if fish were using the restored habitats and if some species favored the new habitat (Hobbs and others, 2015b, 2015d). For the most part, the assemblage and relative abundance of aquatic organisms were similar between tidally restored ponds and adjacent sloughs (fig. 13, upper graphs). This is likely the result of the high degree of tidal connectivity between pond and slough habitats as most of the water within tidal ponds is exchanged with sloughs during the tidal cycle. The seasonal and between-year variability in the newly restored tidal ponds reflects the fluctuations observed in other California bays and estuaries due to variability in freshwater outflow, salinity, temperature, and life histories of aquatic organisms. Abundance and diversity were greatest in spring, when offspring of many organisms grow large enough to be caught in nets, but decreased in summer when DO concentrations are low. Species assemblage differences were greatest in winter, with the arrival of migratory species, including the longfin smelt (Spirinchus thaleichthys), which is currently listed as threatened by the State Endangered Species Act (fig. 12). Longfin smelt were consistently utilizing the tidal restoration ponds in winter, and at times, much more abundant within the ponds where the density of mysid shrimp, a favorite food for smelt, occurred in high densities. Several species increased in abundance over time during trawl surveys in the Alviso Marsh, and some species tended to occur more frequently or in higher numbers in tidal restoration ponds, such as northern anchovy and shiner surfperch. This may represent the benefits of tidal pond restoration. Other species did decrease during the study period (for example staghorn sculpin and three-spine stickleback), but this was likely due to extremely low freshwater flows due to the drought.

Jim Hobbs also conducted studies to determine if leopard sharks (Triakis semifasciata), a top predator, utilize recently restored Project ponds (Hobbs and others, 2015a). Surveys were conducted among restoration sites with fully tidal restored ponds, muted-tidal ponds, and adjacent tidal slough habitat. Young-of-year sharks and pregnant females were captured in restoration ponds (tidal and muted-tidal ponds) from March to November. The survey examined the abundance of leopard sharks as a measure of response to restoration actions. Diets of leopard sharks were also evaluated to determine if the type of restoration influences shark diet. Leopard sharks occurred about three times more frequently in tidal sloughs and fully tidal ponds compared to muted-tidal ponds. Diet composition, condition, and stomach fullness were similar among the restored ponds and slough habitat, suggesting they were finding adequate food supplies in the restored habitats. This suggests restoration of former salt ponds has provided approximately 2,000 acres of a new kind of nursery habitat for leopard sharks.

Collectively, this series of studies suggests fully tidal restoration ponds provide habitat for a diverse assemblage of organisms, functioning as nursery habitat for a variety of important species (such as the longfin smelt) and may facilitate recovery of these species. Managed ponds also supported great abundance of organisms; however, these were mostly non-native species. To maximize restoration benefits to aquatic and bird species, the trade-offs between fully breached restorations versus muted tidal/managed pond restoration must be weighed. Managed ponds provide relatively stable water levels and provide feeding and resting areas for the benefit of migratory waterbirds, but water-quality conditions inside the ponds may pose challenges for aquatic species. Managed pond water quality in summer can be poor, with DO concentrations decreasing well below suitable levels for fish. Because managed ponds are often supersaturated in DO during the daytime, this condition could provide benefits to the adjacent sloughs as oxygenated water enters the sloughs from the ponds on an ebb tide. Improving connectivity between managed ponds and sloughs may alleviate some of the water-quality issues and may facilitate exchange of aquatic organisms, allowing mobile organisms to escape poor water quality, preventing fish kill events (Valoppi and others, 2014; La Luz and others, written commun., 2015). 
Data on harbor seal haul-out areas in lower South Bay have been collected from weekly surveys conducted by volunteers with the Don Edwards San Francisco Bay National Wildlife Refuge since 1999. Molting season and pupping season harbor seal abundances have fluctuated over the study period, but overall numbers are above or in the range of levels observed in 1999. Harbor seal numbers appear to be holding steady. It is not well understood if tidal restoration has benefited harbor seals, but an increase in fish should provide them with more feeding opportunities.

\begin{tabular}{|l|l|l|}
\hline & $\begin{array}{l}\text { Key Uncertainty: Can restoration be configured to maximize benefits to non-avian } \\
\text { species onsite and in adjacent waterways? }\end{array}$ & Score \\
\hline 1 & $\begin{array}{l}\text { Have the number of steelhead and other salmonids, including juveniles, increased in } \\
\text { rearing and foraging habitats? }\end{array}$ \\
\hline 2 & $\begin{array}{l}\text { Have the number of native adult and juvenile fish increased in estuarine rearing and } \\
\text { foraging habitats? }\end{array}$ & $\begin{array}{l}\text { To what extent will increased tidal habitats increase survival, growth, and reproduction of } \\
\text { harbor seals? }\end{array}$ \\
\hline
\end{tabular}

\section{Management Responses to Phase 1 Studies}

- Managers are working with the National Marine Fisheries Service to determine what management actions, if any, are needed to prevent the trapping of migrating salmon and steelhead.

- Managers changed plans for further breaching of Ponds A21 and A20 based on high fish productivity and satisfactory development of marsh habitat.

\section{Needed Phase 2 Studies for Effects on Aquatic Species}

○ Continue steelhead smolt studies to support continued management of Pond A8 as a muted tidal system year-round.

- Conduct studies assessing the growth and reproductive success of aquatic organisms, especially fish.

- Explore if understanding restoration benefits to harbor seals is needed. 


\section{Water Quality}

The former salt ponds were designed and engineered to hold in Bay water. The South Bay's abundant sun, wind, and warm temperatures in the spring and summer months would evaporate the trapped water, leaving behind sea salt. However, this inherent design makes it a challenge to flow enough water through the system to maintain good water quality to support fish and other aquatic life. The conditions that allow for evaporation in the shallow depths also encourages algae to grow in the ponds. That can be good up to a point, as the algae are food sources for other organisms. However, too much algae can consume too much DO in the water, resulting in poor water quality and even fish dieoffs. Shortly after purchasing the property, the Project installed about 53 additional water- control structures to allow more bay water to flow into the ponds, and to allow water to be transferred between ponds. Although this has stopped salt production and increased circulation, the challenge remains for managers to maintain water quality while providing habitat to a wide diversity of wildlife in the ponds. Additionally, as ponds were breached for full tidal restoration, pond water would mix with water in the adjacent sloughs. It was unknown what effect that would have on the surrounding bay habitats.

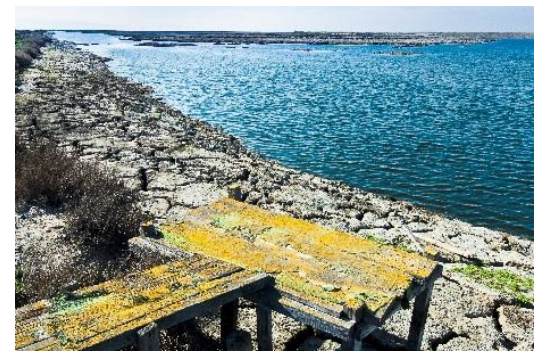

Pond sediment and water view.

Photograph by Pelican Media.

\section{Key Uncertainty}

Will restoration adversely affect water quality and productivity?

Question 1. What is the effect of (a) pond management, including increased pond flows and associated managed pond effects, and (b) increased tidal prism from tidal habitat restoration on water quality, phytoplankton, and fish diversity and abundance, and food web dynamics in South Bay? 
Jan Thompson of the USGS analyzed bottom-dwelling invertebrate samples collected during 3 seasons in each of 3 years prior to the restoration project (1993-95) and after the restoration activities started (2006-08) (Thompson and Parchaso, 2012). There have been changes in the invertebrate community since the restoration began, but it is impossible to separate the effect of restoration from other factors. The major differences in the invertebrate community between years were the result of a decrease in large, bivalve filter feeders (that are phytoplankton consumers), such as the introduced overbite clam (Potamocorbula amurensis), and the increase in bivalve predators such as Bay shrimp (Crangon spp.) and Dungeness crab (Metacarcinus magister). The invertebrate community was dominated by large bivalve filter feeders until 1999 and thereafter by small, non-bivalve filter feeders (amphipods) and deposit feeders, as the bivalves declined. The invertebrate communities continued to be dominated by small filter feeders/deposit feeders, and no changes could be attributed to restoration activities during that time period.

Dave Schoellhamer and Gregg Shellenbarger of the USGS have analyzed 2 decades of salinity and temperature data collected from 1982 to 2002 in the San Francisco Estuary (Shellenbarger and Schoellhamer, 2011). The water temperature at the Dumbarton Bridge station, the gateway into the lower South Bay, has shown a decreasing trend, even when corrected for air temperature trends. A decreasing trend in air temperature was identified for 1988-2002, but not 1988-98. Authors note that the South Bay region has a higher surface area to volume ratio due to the extensive shallow water and mudflat habitats, compared to much of the rest of the San Francisco Estuary, so the South Bay would be expected to respond quickly to changes in air temperatures. High water temperatures allow for more algae to grow. Therefore, when warm bay water enters the shallow pond systems, the warm conditions inside the ponds are conducive to algal growth. This can result in large algae mats and algal blooms in the ponds, a condition that has been observed frequently in the summer months in some ponds. As amount of algae increases, some portion of the algal biomass dies, which increases the amount of oxygen used (due to microbial decomposition of the organic matter from the dead algae), which results in a decrease in DO in the water. This issue is typically more severe in the summer and can lead to low or depleted oxygen conditions in sections of the ponds, which can be detrimental to fish and other aquatic organisms in the pond. These low or depleted oxygen waters could enter the adjacent sloughs during the tidal cycle and adversely affect fish and other organisms in the sloughs.

An early, preliminary study by Dave Schoellhamer and Gregg Shellenbarger investigated the natural variability in DO in sloughs adjacent to ponds (Shellenbarger and others, 2008). The results showed that natural tidal variability during spring and neap tides in the slough appeared to dominate and control the slough DO concentrations, thus minimizing any impact on DO from altering the amount of pond discharge. At times, the pond discharge actually increased DO in the sloughs; for example, during lower low water tides during spring tides. During such times, the tides are larger, allowing for a longer discharge period, allowing higher DO water from the center of the pond to exit at the discharge point. During neap tides, DO concentrations are usually higher in the slough than in the ponds because the tides are smaller, not as much water is discharged from the pond, and water is pulled from closer to the discharge point where algae growth is often greatest and DO lower than in the center of the pond. 
Maureen Downing-Kunz and Greg Shellenbarger of the USGS and David Senn of San Francisco Estuary Institute have been studying the effect of shallow water habitat, such as the managed ponds, along with nutrient inputs from three wastewater-treatment plants on water quality in the lower South Bay (fig. 14) (Novic and others, 2015; Senn and others, 2015). The preliminary results from this study show that low DO is common and variable in sloughs and creeks in lower South Bay, and there is a strong tidal influence to the phenomenon. There is also variability in DO on a daily and seasonal basis. There are multiple factors at work in this complex system and much is unknown. So far, it appears that opening the gates at Pond A8 water control structure to allow water to flow into Alviso Slough has increased the minimum DO concentrations in the slough compared to without the gates open, which can be seen as a benefit to the system. With the gates open all year starting in 2015, 1 year of data suggests that this operation increased DO in the winter months, but also increased DO and reduced the fluctuations in DO, in particular the extreme low values, in summer (fig. 15). A potential negative aspect of opening the gates all year round is that it appears to lead to super-saturated DO conditions that also may have adverse effects on aquatic life. This study shows that the managed ponds do affect water quality in the adjacent sloughs and open bay, but the relative effects of the ponds versus other shallow habitats or nutrient inputs from wastewater treatment plants is still being determined. More work is needed to understand the spatial variability of primary production and other processes affecting water quality within the ponds. It is also not fully understood what can be done to manage the ponds in such a way to minimize water quality problems, given there are limited water control structures in place, and the benefits these managed ponds provide to hundreds of thousands of birds as nesting, foraging, and roosting habitat.

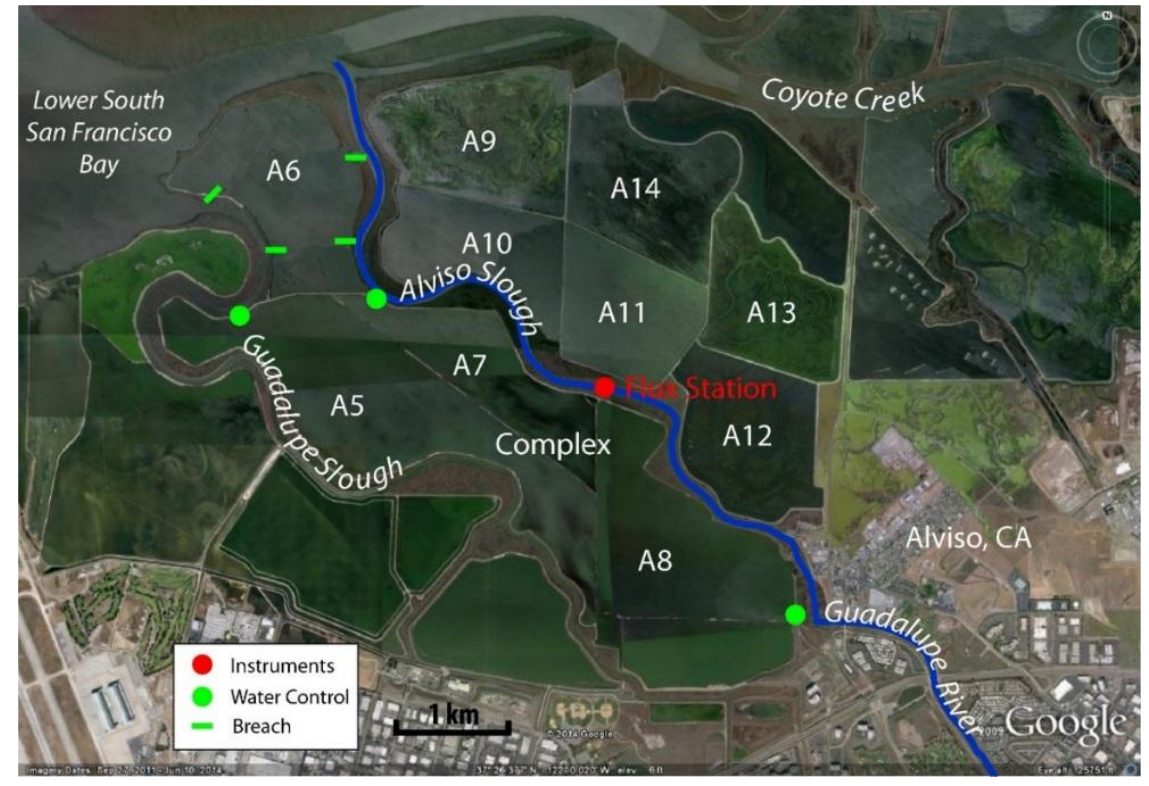

Figure 14. Map showing location and features of water quality studies in Alviso Complex, South Bay Salt Pond Restoration Project, California. Graphic courtesy of Maureen Downing-Kunz, U.S. Geological Survey. 


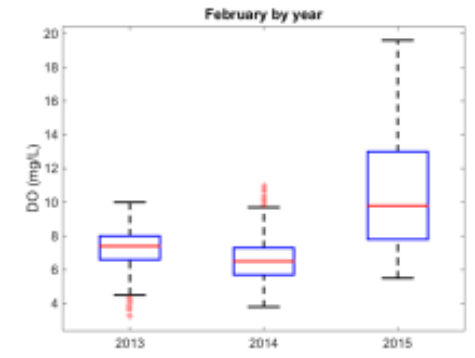

February:

Gates closed except 2015

During 2015, DO increased in

min value, max value, median

value, and range

August:

Gates always open

Over 4 years, low DO

conditions improving; during

2015, the minimum summer

value increased to $\sim 3 \mathrm{mg} / \mathrm{L}$

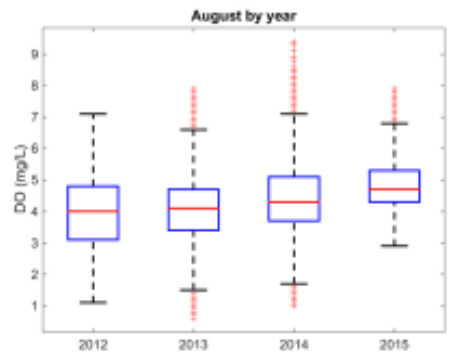

Figure 15. Graphs showing A8 gate operations effects on dissolved oxygen (DO) in Alviso Slough (mid-slough station), South Bay Salt Pond Restoration Project, California. Graphic courtesy of Maureen Downing-Kunz, U.S. Geological Survey.

Studies by James Hobbs found similar water quality between a managed pond and the adjacent Alviso Slough, although managed ponds are fundamentally different in that they experience daily cycles of low oxygen conditions (for example, at night) (Hobbs and others, 2015). The seasonally poor water quality in some of the ponds means they become poor fish habitat during certain times of the year. As an example, fish studies by Dr. Hobbs found that the diversity of the fish community within the Ravenswood SF2 pond was extremely low, despite reaching high abundances in summer months. The warm temperature and low DO concentrations at night $(<1 \mathrm{mg} / \mathrm{L})$ exceed the lethal limits of fish species common in the adjacent bay. It is clear that poor water quality within the pond precludes most species from entering and remaining in this habitat throughout much of summer and fall, although the species that are present are in high numbers. However, during the cooler months, managed and restored ponds can be quite productive, providing habitat for a large number of aquatic species (refer to previous chapter on aquatic species).

Brent Topping of the USGS studied the role of nutrients and DO in Alviso Pond A3W to better understand the role of nutrients in the sediments of the pond, in the water going in and out of the pond, and the effect in the overlying water quality (Topping and others, 2009, 2013). They found that nutrients (nitrogen, phosphorous, silicon) show consistent movement from sediment to the water column during the summer algal growing season. This movement of nutrients from sediment to water is greater and more variable inside the ponds than observed in the open South San Francisco Bay. These elevated nutrient concentrations in the pond sediments likely accumulated during several decades of operation as salt ponds. This research indicates that the reservoir of nutrients in the pond sediments is an important, and at times the most important, source of nutrients that stimulate phytoplankton growth in the water column. When the phytoplankton die-off, or during night-time respiration, they can use up the available oxygen, resulting in very low oxygen conditions in the water that is undesirable for fish and other aquatic life. Long-term improvements in water quality within the pond likely will eventually lead to decreases in the nutrient concentrations in the sediment and porewater as the nutrients move out of the sediment or as new sediment (less nutrient-rich) settles on the pond bottom. 


\begin{tabular}{|l|l|l|}
\hline & $\begin{array}{l}\text { Key Uncertainty: Will restoration adversely affect water quality and productivity and } \\
\text { algae? }\end{array}$ & Score \\
\hline 1 & Has South Bay water quality remained above baseline quality levels? & $\begin{array}{l}\text { Has the Project avoided releasing nuisance and invasive species of algae to the Bay and } \\
\text { producing algal blooms that cause low DO in managed ponds? }\end{array}$ \\
\hline
\end{tabular}

\section{Management Responses to Phase 1 Studies}

- A Water Quality Working Group comprised of managers and researchers has been formed to discuss latest research into water quality in shallow areas of South Bay, and explore potential management options.

- Managers actively monitor managed ponds for signs of low DO and fish kills, notify regulatory agencies of problems, and alter pond operations as much as possible to minimize algal blooms, low DO and fish kills.

- Managers meet with regulatory agencies and apprise them of water-quality impacts from pond management.

- Fish screens have been included in some of the managed ponds, but their efficacy at keeping out fish is unclear. Managers are working with regulatory agencies to determine the need for and design of fish screens.

\section{Needed Phase 2 Studies for Water Quality}

- Better understand the contribution of local wastewater-treatment plants' effluent to nutrient and low DO conditions in the bay and sloughs that feed into the ponds. The Lower South Bay Nutrient Study may help this understanding, and once that study is completed, the Water Quality Working Group can determine additional studies needed.

- Study how pond management can improve water quality, phytoplankton, and fish diversity and abundance and food web dynamics in all the pond complexes. 


\section{Invasive and Nuisance Species}

The main invasive and nuisance species that the Project has focused on so far has been California gulls. Gulls encroach on shorebird and tern nesting areas as well as prey on these species. The total number of California gulls in the Bay has increased exponentially from a few hundred birds in the 1980 s to more than 47,672 birds as of 2015 .

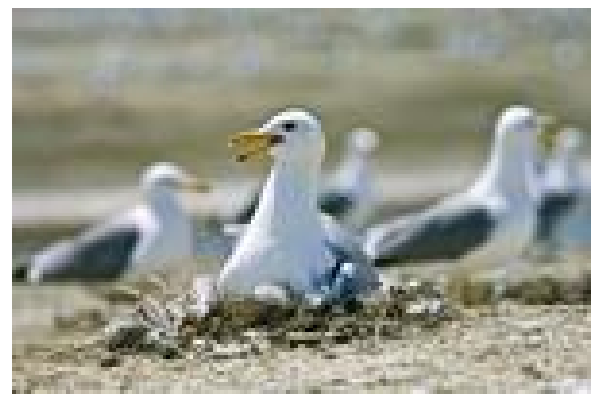

Nesting California gull. Photograph by Pelican Media.

Two studies by Caitlin Robinson-Nilsen and Jill Bluso-Demers of the San Francisco Bay Bird Observatory used remote cameras to identify predators and document the high predation rates of the threatened western snowy plover (Robinson-Nilsen and Bluso Demers, 2011, 2012). Twenty to 60 percent of the nests have been predated by a variety of species. Studies from 2009 to 2011 found California gulls responsible for 6 out of 16 depredation events. Gulls were also the only predator recorded in every year of the 3-year study. Studies from 2015-16 documented the common raven (29 predation events) and peregrine falcon (Falco peregrinus) (1 event) as nest predators. However, the California gull was the most numerous avian predator counted during avian predator surveys.

\section{Key Uncertainty}

Can the existing number and diversity of migratory and breeding shorebirds and waterfowl be supported in a changing (reduced salt pond) habitat area?

Question 1. Will the habitat value and carrying capacity of South Bay for nesting and foraging migratory and resident birds be maintained or improved relative to current conditions?

Question 2. Will shallowly flooded ponds or ponds constructed with islands or furrows provide breeding habitat to support sustainable densities of snowy plovers while providing foraging and roosting habitat for migratory shorebirds?

Question 3. Will ponds reconfigured and managed to provide target water and salinity levels significantly increase the prey base for, and pond use by waterfowl, shorebirds and phalaropes/grebes compared to existing ponds not managed in this manner? 
Josh Ackerman of the USGS documented predation on nesting waterbirds such as plovers, terns, avocets, and stilts by California gulls (Ackerman and others, 2013; Ackerman, Herzog, Hartman, and others, 2014; Ackerman, Herzog, Takekawa, and others, 2014). Overall, California gulls were the predominant predator of American avocet and Forster's tern chicks in San Francisco Bay, causing 55 percent of avocet and 54 percent of tern chick deaths. Additionally, California gulls were responsible for 13 percent of egg depredations at avocet nests and 38 percent of egg depredations at western snowy plover nests. It also appears that some individual California gulls specialize in depredating Forster's tern chicks. The overall survival of chicks from hatching to fledging was generally low- 6 percent for avocets, 22 percent for terns, and 40 percent for stilts.

Managers anticipated that the breaching Pond A6, where the highest number of breeding California gulls nested, would disperse the gulls to other locations and thereby decrease predation pressure on plovers and terns. The breaching of Pond A6 in 2010 resulted in the relocation of about 26,000 breeding California gulls, the largest colony in San Francisco Bay, and led to the increase in an adjacent colony at Ponds A9, A10, A11, and A14 (42 percent of the California gulls population) (Burns and Taketa, 2013). Although breeding California gulls decreased initially from 2010 to 2011, by 2012 the number of California gulls again increased; so flooding of Pond A6 only decreased gull numbers for 1 year. Researchers examined the effect of the Pond A6 breach, and thus the gull colony relocation, by looking at the change in Forster's tern chick survival between 2010 and 2011 at the adjacent Pond A7 tern colony (Ackerman, Herzog, Hartman, and others, 2014). After the Pond A6 breach, tern chick survival at the tern colony in A7 increased from 4 percent in 2010 to 40 percent in 2011. The increased chick survival was not observed at the more distant tern colony at Pond A2W (25-29 percent chick survival). Among 19 tern colonies studied, fledging success was higher when gull abundance was lower at nearby colonies and when gull colonies were farther from the tern colony. These results suggest that young tern chicks at Pond A7 benefited in the short term from the gull colony relocation from Pond A6. Even though most California gulls moved to nesting locations not far away, there was apparently enough of a distance to increase tern chick survival at Pond A7.

In 2011 and 2012, Caitlin Robinson-Nilsen, Karine Tokatlian and Christine Donehower of the San Francisco Bay Bird Observatory conducted intensive surveys and nonlethal California gull hazing in sensitive areas to protect western snowy plover against California gulls impacts (Donehower and others, 2013). Cheryl Strong from the U.S. Fish and Wildlife Service led these efforts in 2013 and 2014, and U.S. Fish and Wildlife Service and San Francisco Bay Bird Observatory teamed up again in 2015 to conduct these efforts. Additionally, the nearby landfill at Newby Island has implemented an effective gull abatement program. These efforts have resulted in successfully deterring California gulls from nesting in designated sensitive areas. In the last 2-3 years, the rate of increase in the number of California gulls appears to have slowed (Burns and others, 2016). So the long-term impact of California gulls on nesting waterbirds is still unclear. 


\begin{tabular}{|l|l|l|}
\hline & $\begin{array}{l}\text { Key Uncertainties: Does invasive Spartina and hybrids significantly decrease aquatic } \\
\text { species and shorebird uses? Will California gulls, ravens, and crows adversely affect } \\
\text { (through predation and encroachment on nesting areas) nesting birds in managed } \\
\text { ponds? }\end{array}$ & Score \\
\hline 1 & $\begin{array}{l}\text { Is marsh vegetation establishment trending toward reference marsh quality? } \\
2\end{array}$ & $\begin{array}{l}\text { Will California gulls and other predators adversely affect nesting birds in managed } \\
\text { ponds? }\end{array}$ \\
\hline
\end{tabular}

\section{Management Responses to Phase 1 Studies}

- Managers have initiated and will continue hazing of gulls from sensitive areas used by other breeding birds.

- Managers will continue to pursue funding to conduct habitat enhancement projects, such as the use of shells to enhance breeding plover habitat, to reduce the impacts of California gulls on breeding birds.

\section{Needed Phase 2 Studies for Effects on Invasive and Nuisance Species}

- Explore how to reduce regional breeding populations of California gull. A directed study to understand California gull reproductive success (nest success, chick growth, and survival) and gull movements is needed.

$\circ$ Fund predator management efforts and study the effects of predator control and removal on tern and plover nesting success.

- Continue study of habitat enhancement techniques to decrease gull predation on nesting snowy plover, avocets, and Forster's terns. 


\section{Public Access and Wildlife}

One of the Project goals is to provide wildlife-compatible public access and facilities for the 4 million people living in the South Bay. However, this needs to be done in a way that does not impact the wildlife and resources that are being protected and restored. Phase 1 studies focused on trail-user impacts on birds; studies evaluating boating access on harbor seals were not conducted.

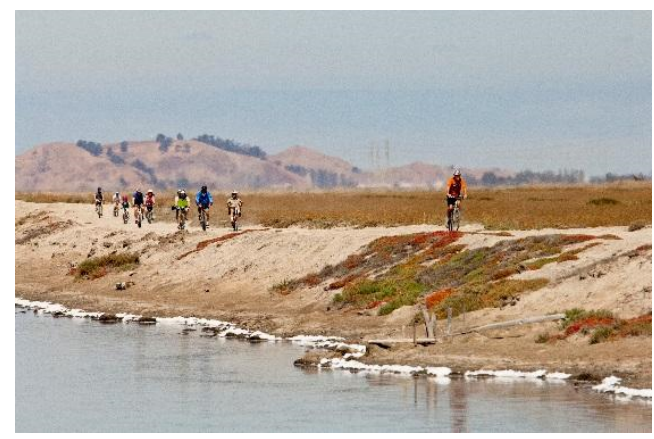

Recreational use of pond levees. Photograph by Pelican Media.

Lynne Trulio of San Jose State University studied the response of wintering shorebirds, ducks, and nesting snowy plovers to trail users (Trulio and others, 2011, 2012, 2013). These studies provided estimates of "safe distances" or buffer distances needed between a trail and habitat for these birds. The studies found that keeping trail users approximately 164 feet from shorebird foraging habitat prevented nearly all trail walker disturbances to the dominant wintering foraging shorebirds, especially western and least sandpipers (Calidris mauri and Calidris minutilla), dunlin (Calidris alpine), willet (Tringa semipalmata), and yellowlegs (Tringa melanoleuca and Tringa flavipes).

\section{Key Uncertainty}

Will trails and other public access features / activities have significant negative effects on wildlife species?

Question 1. Will increases in boating access significantly affect birds, harbor seals, or other target species on short or long timescales?

Question 2. Will landside public access significantly affect birds or other target species on short or long timescales?

Question 3. Will public access features provide the recreation and access experiences visitors and the public want over short or long timescales? 
For wintering waterfowl, this research indicated that trails should be at least 400 feet from waterfowl foraging areas at ponds to minimize waterfowl disturbance impacts on waterfowl use. It is also suggested that significant areas without trails be established to minimize disturbance to waterfowl foraging and resting habitat. Researchers suggest it would be beneficial to increase quality forage within ponds at locations more than 400 feet from trails. Additionally, they suggest concentrating public access in popular areas, and whenever possible, close very low use trails or close them temporarily during the winter migratory season when the peak number of birds is present.

For nesting snowy plovers, the data suggest new trails at least 492 feet from plover nesting habitat to reduce disturbance. These studies were for trail walkers - other trail users, such as bicyclists, joggers, large groups, and dogs, could lead to greater disturbance of plovers, such as longer flush distances or longer times off the nest.

Lynne Trulio also conducted a trail user survey to assess the satisfaction of the existing trails by users and to understand what types of facilities and experiences were most desirable (Trulio and Sokale, 2013). Overall satisfaction with their trail experience was high, with 97 percent being satisfied or very satisfied. Visitors cited the beauty, quiet and safety of the trails. They remarked on the abundance of birds/wildlife, lack of crowds, cleanliness and the relaxing nature of the experience. The physical features respondents found most attractive ( $>60$ percent favoring) were an overlook or view area, parking, maps/signs, restrooms, and the presence of wildlife. The primary response provided for trail preference can be summarized in one word-access. Survey participants noted "close to home," "close to work," "convenient," "nearby," and "easy access" for their favorite route. The top two concerns were the potential for too many trail users and perceived unsafe conditions. Respondents felt that future expenditures should focus on completing the Bay Trail and connecting to existing trails/roadways to enhance pedestrian and bicycle access; promoting trail and transit connections; and ensuring adequate Project funding for on-going trail maintenance. 


\begin{tabular}{|l|l|l|}
\hline & $\begin{array}{l}\text { Key Uncertainty: Will trails and other public access features/activities have } \\
\text { significant negative effects on wildlife species? }\end{array}$ & Score \\
\hline 1 & $\begin{array}{l}\text { Will public access features provide the recreation and access experiences visitors } \\
\text { and the public want over short or long timescales? }\end{array}$ & \\
\hline 2 & $\begin{array}{l}\text { Will landside public access significantly affect birds or other target species on short } \\
\text { or long timescales? }\end{array}$ \\
\hline
\end{tabular}

\section{Management Responses to Phase 1 Studies}

- Managers incorporated trail buffer distances into the design of Ponds SF2, A16, and E12/E13 placement of islands.

- Managers will be designing future trails utilizing recommended buffer distances.

\section{Needed Phase 2 Studies for Public Access and Wildlife}

- Study responses of trail use by tidal marsh species: where are displaced populations going, if they are leaving the area due to trail use?

- Study the impacts of boat launch use on species.

- Social carrying capacity study; study ethnic groups use of public access areas as surveys indicated low use by some ethnic groups.

- Explore the impact of differing levels of trail use on the health of migratory birds using the estuary. 


\section{Climate Change and Sea-Level Rise}

Although one of the major goals of the Project is to restore former salt ponds to tidal marsh, managers are also concerned that predicted changes in climate, particularly increased rates of sea-level rise, would result in flooding the restored marshes and thereby undo the benefits of tidal marsh restoration for wildlife and people.

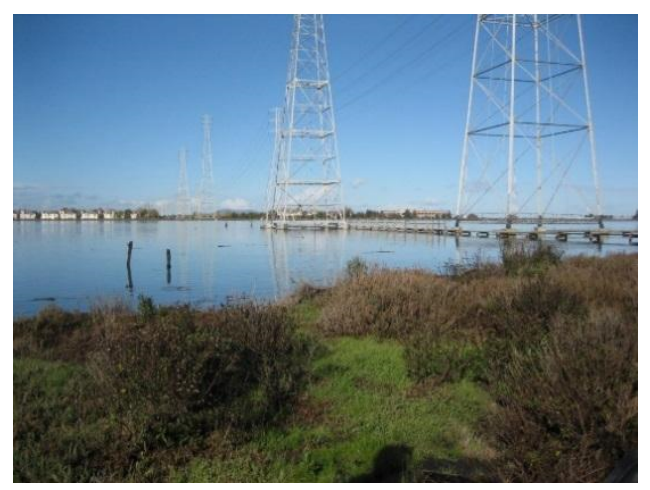

King tide inundates marsh. Photograph by Laura Valoppi.

Several researchers have investigated the predicted response of tidal marshes to future rates of sea-level rise in San Francisco Bay. Although there is considerable uncertainty to the rate of sea-level rise, particularly after about 2050, due to uncertainties in global carbon emission rates, there is a general consensus among scientists that sea levels on the West Coast are predicted to rise by 2-12 inches by 2030, 5-24 inches by 2050, and 17-66 inches by 2100, relative to levels in 2000 (National Research Council, 2012).

Different approaches to modeling the effect of sea-level rise on tidal marsh sustainability have been investigated. These are on-going efforts by others. Diana Stralberg of Point Blue Conservation Science, estimated the spatial distribution of marsh accretion using the Marsh98 model, and considered the variation in tidal range throughout the San Francisco Bay (Stralberg and others, 2011). They varied the rate of sea-level rise (20-65 inches) and varied the amount of organic matter and suspended sediment that was available for marsh accretion based on regions in the bay. They found that marshes with low suspended sediment would not be sustained for more than 40 years under any of the sea-level rise rates. At the other end of the spectrum, marshes with high levels of suspended sediment (such as the South Bay) were sustained up to 80 years, but not over the full 100 years. The model projected that even under the most pessimistic of assumptions (low suspended sediment, high rates of sea-level rise), that there would be a bay-wide increase in marsh habitat until about 2050, suggesting that a large-scale effect of sea-level rise may not be seen until close to 2100 . After 2100, with predicted increased rates of sea-level rise, loss of marsh habitat would also increase. To minimize marsh loss, the authors recommend conserving adjacent uplands for marsh migration, redistributing dredged sediment to raise existing elevations of ponds prior to restoration, and concentrating restoration efforts in sediment-rich areas. 
Key Uncertainties: Although climate change and sea-level rise have not been specifically identified in the Adaptive Management Plan as a key uncertainty, it is of concern to

managers.

Some of the questions posed by managers include:

Question 1: Will South Bay marshes keep pace with sea level rise by 2050? By 2100?

Question 2: To conserve San Francisco Bay tidal marshes in light of future climate change, what management, restoration, and adaptation strategies, if any, should be conducted, and where, when, and how should they be conducted?

Lisa Schile of the University of California, Berkeley built upon Marsh98 by incorporating plant productivity to predict marsh resiliency using the Marsh Equilibrium Model (MEM), and calibrating the model with extensive data collected from four tidal marshes in San Francisco Bay Estuary (all collected from the Delta or North Bay) (Schile and others, 2014). The MEM model was run using five rates of sea-level rise (about 22-70 inches/century) and three suspended-sediment concentrations, with sea-level elevations projected for 2030, 2060, 2080, and 2110. As with the Marsh98 model, marsh accretion did not keep pace with sea-level rise under low suspended-sediment concentrations. Model results indicated that tidal wetlands were able to keep pace with sea-level rise up to a "tipping point," specifically when the sea-level rise rate was greater than 39 inches/century. Researchers stressed that adjacent upland areas could provide space for the marsh to migrate under the highest rates of sea-level rise.

John Takekawa and Karen Thorne of the USGS, took another approach by collecting detailed and site-specific elevation, tidal inundation, and vegetation data at 12 marshes around San Francisco Bay, along with sediment cores, to provide inputs to the Wetland Accretion Rate Model for Ecosystem Resilience model (WARMER)(Takekawa and others, 2013). Model results indicated that 96 percent of the areas studied would become mudflat habitat by 2100 , assuming a 49 inch sea-level rise rate. Variations in tidal range, marsh accretion rates, and initial marsh elevation at the different study sites resulted in varying risks to sea-level rise. They found that marsh accretion rates were relatively high in South Bay, and thus those tidal marshes withstood sea-level rise effects longer, but with many areas transitioning to only low marsh by 2100 . The two study sites that are closest to the Project area are Cogswell Marsh along the Hayward Regional Shoreline (just north of Eden Landing Ecological Reserve), and Laumeister Marsh owned by the City of Palo Alto, (located south of the Ravenswood Complex). The WARMER model results showed that Cogswell Marsh had a gradual reduction in elevation, with an increased decline after 2060. Due to high accretion rates, due partly to high suspended-sediment concentrations in South Bay, mid-marsh habitat was maintained through 2070 (assuming about 26 inches of sea-level rise). Cogswell marsh was projected to transition to low-marsh habitat by 2100 (48 inches of sea-level rise). Model results for Laumeister Marsh showed it was able to sustain itself longer due to its high initial elevation and marsh accretion rates, and partly to high suspended sediment. Laumeister Marsh is expected to sustain high-marsh habitat through 2060 (about 22 inches of sea-level rise), transition to mid-marsh habitat by 2080, and would be mostly low-marsh habitat by 2100 (48 inches of sea-level rise). 
Although these model results are encouraging for the sustainability of marshes in South Bay relative to other areas of the Bay, it is unknown what the sustainability of subsided managed ponds will be under future restoration efforts.

Karen Thorne of the USGS applied a structured decision making process and expert judgment to develop alternative management strategies to increase tidal marsh resiliency through 2050 (Thorne and others, 2015). They sought to optimize a strategy for tidal marsh conservation that took into account future marsh accretion uncertainties, along with social and economic risks, ecological benefits, and trade-offs. This prototype effort sought to answer the question, "To conserve San Francisco Bay tidal marshes in light of future climate change, what management, restoration, and protection actions, if any, should be conducted, and where, when, and how should they be conducted?" They used two time horizons of 2020 and 2050, based on current restoration planning efforts. The results of this process found the greatest utility would be from a "climate-smart" restoration allocation of resources. Such an approach includes increasing resiliency of tidal marshes to climate effects by exploring engineering options to improve resiliency of future marshes; retrofit ongoing or past marsh restorations, and enhance historical marshes; accelerate the timeline for tidal marsh restoration using fill to raise marsh elevations; and restoration of areas with the highest marsh accretion potential.

One intriguing climate-smart adaptation strategy is shallow-water dredged material placements to allow natural processes to replenish sediments to marsh and mudflat habitats. Aaron Bever of Anchor QEA, in collaboration with the U.S. Army Corps of Engineers, studied the in-bay placement of dredge material at two locations in Corte Madera Bay, two locations in San Pablo Bay and four locations in far South Bay (Bever and others, 2014). The authors applied a three-dimensional hydrodynamic, wave, and sediment transport model to evaluate whether strategic placement of dredged material in less dispersive areas adjacent to existing marshes or breached ponds would result in an increase in sediment deposition within the marshes and ponds through natural dispersal processes. Dredged material placement simulations in far South Bay indicated that the natural dispersal of sediment from open water in-bay placement has the potential to be used to augment mudflat, marsh, and pond sedimentation in the far South Bay. Placement regions in the far South Bay were much more effective at supplying sediment to mudflats and marshes than locations in San Pablo Bay or Corte Madera Bay, and supplied less sediment to Federal navigation channels than the San Pablo Bay or Corte Madera sites evaluated. The implementation of a pilot project of an in-bay, strategic placement of dredged material, together with a detailed monitoring study and additional modeling, is needed to provide data to further validate the model and demonstrate the effectiveness of this strategy.

Managers have begun various actions to plan for and mitigate against future levels of sea level rise (Valoppi and others, 2015). 


\section{Management Responses to Phase 1 Studies}

- Managers have engaged with modelers to develop Project specific marsh sustainability projections and develop the best strategies for deciding which ponds to restore and in what order.

- Phase 2 actions will focus almost solely on marsh restoration projects in order to establish marsh habitat prior to increased rates of sea-level rise in the future. The rationale is because established marsh has a better chance to keep pace with sea-level rise than a newly created marsh.

- Managers have begun planning for marsh enhancement features such as marsh mounds and upland transition zones to be incorporated in the design of Phase 2 restoration projects, as was done in Phase 1 projects. Such features are believed to provide high-water refuge habitat for endangered species and add natural features to the landscape.

- Managers have secured supplies of clean upland fill material and have been utilizing the soil to enhance berms and begin to create transitional habitat between the upland and the marsh.

- Managers have also investigated the feasibility of beneficial reuse of dredge material and are working with local ports and the U.S. Army Corp of Engineers.

- Managers are working with modelers to investigate novel approaches to application of dredge materials to marshes and mudflats to provide a sediment under future sea-level rise.

\section{Needed Phase 2 Studies for Climate Change and Sea-Level Rise}

- Evaluate marsh sustainability models for application to subsided ponds in order to develop scenarios for optimal sequence of restoration and rate of marsh restoration actions.

- Evaluate options for increasing initial pond elevations for marsh restoration through bringing in upland fill and the beneficial reuse of dredge sediments.

- Explore the creation of marsh-upland transition zones as part of marsh restoration efforts to provide migration space for marshes as an adaptation strategy for future sea-level rise projections.

- Implement a pilot project to further evaluate in-bay sediment placement models and further develop the technique as an adaptation strategy.

- Implement studies to evaluate the sediment availability for marsh restoration and accretion in relation to future sea-level rise. 


\section{References Cited}

Please visit the website to find these documents, and more:

http://www.southbayrestoration.org/science/.

\section{Introduction}

Trulio, L., Clark, D., Ritchie, S., Hutzel, A., and Science Team, 2007, Appendix D—Adaptive management plan, in U.S. Fish and Wildlife Service and California Department of Fish Game, South Bay Salt Pond Restoration Project Environmental Impact Statement/Report, volumes 1 and 2: Prepared by EDAW, Philip Williams and Associates, Ltd., H.T. Harvey and Associates, Brown and Caldwell, and Geomatrix, submitted to U.S. Army Corps of Engineers, U.S. Fish and Wildlife Service, and California Department of Fish and Game, March 2007, 143 p., http://www.southbayrestoration.org/pdf_files/SBSP_EIR_Final/ Appendix\%20D\%20Final\%20AMP.pdf.

U.S. Fish and Wildlife Service and California Department of Fish Game, 2007, South Bay Salt Pond Restoration Project Environmental Impact Statement/Report, volumes 1 and 2: Prepared by EDAW, Philip Williams and Associates, Ltd., H.T. Harvey and Associates, Brown and Caldwell, and Geomatrix, submitted to U.S. Army Corps of Engineers, U.S. Fish and Wildlife Service, and California Department of Fish and Game, March 2007 final, http://www.southbayrestoration.org/EIR/.

Valoppi, L., Ackerman, S., De La Cruz, C., Robinson-Nilsen, K., Tokatlian, C., and Strong, 2015, South San Francisco Bay salt pond restoration-Adaptive management in action: Presentation at the Biennial State of the Estuary Conference, 13th Oakland, Calif., September 17-18, 2015, http://www.sfestuary.org/wp-content/uploads/2015/08/SOE2015ProgramV2.pdf.

Valoppi, L., and Bourgeois, J., 2014, Adaptive management in action-South San Francisco Bay salt pond restoration project: National Harbor, Maryland, Restore America's Estuaries 7th National Summit on Coastal and Estuarine Restoration and the 24th Biennial Meeting of The Coastal Society, November 1-6, 2014.

Valoppi, L., Bourgeois, J., and Strong, C., 2014a, Communicating science-South Bay salt pond restoration project: Sacramento, Calif., Bay-Delta Science Conference, October 28-30, 2014, poster presentation,http://www.southbayrestoration.org/science/BDSC2014/

BayDelta_Communicating\%20Science_2014_Poster_Valoppi_Final.pdf.

Valoppi, L., Bourgeois, J., and Strong, C., 2014b, South Bay restoration project-Adaptive management in action: Sacramento, Calif., Bay-Delta Science Conference, October 28-30, 2014, http://www.southbayrestoration.org/science/BDSC2014/

BayDelta_AM\%20in\%20Action_2014_Poster_Valoppi_Final.pdf.

\section{Marsh, Mice, and Rails}

Goals Project, 2015, The baylands and climate change-What we can do-Baylands ecosystem habitat goals science update 2015: Oakland, Calif., prepared by the San Francisco Bay Area Wetlands Ecosystem Goals Project, California State Coastal Conservancy.

Liu, L., Wood, J., Nur, N., Salas, L., and Jongsomjit, D., 2012, California clapper rail (Rallus longirostris obsoletus) population monitoring - 2005-2011: California Department of Fish and Game, PRBO Technical Report.

Overton, C.T., Casazza, M.L., Takekawa, J.Y., Strong, D.R., and Holyoak, M., 2014, Tidal and seasonal effects on survival rates of the endangered California clapper rail-Does invasive Spartina facilitate greater survival in a dynamic environment?: Biological Invasions, v. 16, p. 1,897-1,914. 
Overton, C.T., Takekawa, J.Y., Casazza, M.L., Bui, T.D., Holyoak, M., and Strong, D.R., 2015, Sealevel rise and refuge habitats for tidal marsh species - Can artificial islands save the California Ridgway's rail?: Ecological Engineering, v. 74, p. 337-344.

Santa Clara Valley Water District and U.S. Fish and Wildlife Service, 2015, Island ponds mitigation monitoring and reporting year 10, 75 p., http://www.southbayrestoration.org/monitoring/ Island\%20Ponds\%20Year\%2010\%20Monitoring\%20Report.pdf.

U.S. Fish and Wildlife Service, 2013, Recovery plan for tidal marsh ecosystems of Northern and Central California: Sacramento, California, U.S. Fish and Wildlife Service, xviii +605 p.

\section{Sediment Dynamics}

Callaway, J.C., Parker, V.T., Schile, L.M., Herbert, E.R., and Borgnis, E.L., 2009, Dynamics of sediment accumulation in Pond A21 at the Island Ponds: Oakland, Calif., submitted to California Coastal Conservancy, 66 p., http://www.southbayrestoration.org/documents/

Callaway\%20et\%20al\%20FINAL\%20Report\%2012\%2009.pdf.

Callaway, J.C., Schile, L.M., Borgnis, E.L., Busnardo, M., Archbald, G., and Duke, R., 2013, Sediment dynamics and vegetation recruitment in newly restored salt ponds-Final Report for Pond A6

Sediment Study: Submitted to Resources Legacy Fund and South Bay Salt Pond Restoration Project, 29 p., http://www.southbayrestoration.org/documents/technical/

Pond\%20A6\%20FINAL\%20report.COMBINED.08.21.2013.pdf.

Foxgrover, A.C., Finlayson, D.P., Jaffe, B.E., and Fregoso, T.A., 2014, Bathymetry and digital elevation models of Coyote Creek and Alviso Slough, South San Francisco Bay, California (ver. 3.0, September 2015): U.S. Geological Survey Open-File Report 2011-1315, 20 p., http://dx.doi.org/10.3133/ofr20111315.

Fulfrost, B., Byrd, K., Valoppi, L., Foxgrover, A., De la Cruz, S., Chen, Y., and Thomson, D., 2015, Incorporating the Coastal Blue Band into a remote sensing toolkit for mapping intertidal mudflats in South SF Bay [poster]: State of the San Francisco Estuary Conference, Oakland, Calif., September 17-18, 2015.

Fulfrost, B., Byrd, K., Valoppi, L., Foxgrover, A., Jaffe, B., Thomson, D., Chen, Y., and De La Cruz, S., 2015, Incorporating the Coastal Blue Band (CBB) aboard satellites and unmanned aerial surveillance (UAS) - A remote sensing toolkit for mapping intertidal mudflats in South SF Bay [presentation]: 2015 Science Symposium, Mountain View, Calif., October 22, 2015, http://www.southbayrestoration.org/science/2015symposium/ presentations/3_9_45_Byrd_Fulfrost_MudFlats_ScienceSymposia2015.pdf.

Fulfrost, B., Thomson, D., Archbald, G., Loy, C., and Fourt, W., 2012, Habitat evolution mapping project-Final report: 91 p., http://www.southbayrestoration.org/documents/technical/HEMP FinalReport 072312.pdf .

Schoellhamer, D., Shellenbarger, G., and Downing-Kunz, M., 2015, South Bay suspended-sediment concentration and supply [presentation]: 2015 Science Symposium, Mountain View, Calif., October 22, 2015, http://www.southbayrestoration.org/science/2015symposium/ presentations/4_10_00_Schoellhamer\%20sbay\%20sci\%20sym\%20Oct\%2022\%202015.pdf. 
Schoellhamer, D., Shellenbarger, G., and Wright, S., 2013, Does central valley runoff control sediment supply to South San Francisco Bay? [presentation]: 2013 Science Symposium, Menlo Park, Calif., July 16, 2013, http:/www.southbayrestoration.org/science/2013symposium/ presentations/1\%20Schoellhamer\%20SBSC\%20July\%2016\%202013\%201.pdf.

Schoellhamer, D., Wright, S.A., and Drexler, J.Z., 2013, Adjustment of the San Francisco estuary and watershed to decreasing sediment supply in the 20th century: Marine Geology, v. 345, p. 63-71, DOI: 10.1016/j.margeo.2013.04.007, http://pubs.er.usgs.gov/publication/70094487.

Shellenbarger, G.G., Downing-Kunz, M.A., and Schoellhamer, D.H., 2014, Suspended-sediment dynamics in the tidal reach of a San Francisco Bay tributary-Proceedings of the 17th Physics of Estuaries and Coastal Seas (PECS) conference, October 19-24, 2014: Porto de Galinhas, Pernambuco, Brazil, http://www.southbayrestoration.org/documents/technical/ shellenbarger_etal_PECS2014_final.pdf.

Shellenbarger, G., Wright, S.A., and Schoellhamer, D.H., 2013, A sediment budget for the southern reach in San Francisco Bay, CA-Implications for habitat restoration: Marine Geology, v. 345, p. 281-293, http://www.southbayrestoration.org/documents/technical/ shell\%20et\%20al\%202013\%20MARGO.pdf.

Valoppi, L., Bourgeois, J., Callaway, J., Jaffe, B., Marvin Di-Pasquale, M., and Shellenbarger, G., 2013, Changing sediment dynamics and mercury remobilization in the South San Francisco Bay Salt Pond Restoration Project: San Diego, Calif., Coastal and Estuarine Research Federation (CERF) Conference, November 3-8, 2013.

\section{Bird Use of Changing Habitats}

Ackerman, J.T., Hartman, C.A., Herzog, M.P., Smith, L.M., Moskal, S.M., De La Cruz, S.E.W., Yee, J., and Takekawa, J.Y., 2014, The critical role of islands for waterbird breeding and foraging habitat in managed ponds of the South Bay Salt Pond Restoration Project, South San Francisco Bay, California: U.S. Geological Survey Open-File Report 2014-1263, 108 p., http://dx.doi.org/10.3133/ofr20141263.

De La Cruz, S.E.W., Smith, L.M., Moskal, S., Strong, C., Krause, J., Washburn, N., and Takekawa, J.Y., 2015, Evaluating wintering waterbird response to the West Coast's largest tidal marsh restoration project [presentation]: 2015 Science Symposium, Mountain View, Calif., October 22, 2015, http://www.southbayrestoration.org/science/2015symposium/

presentations/13_330DeLaCruz.pdf.

Hartman, A., Ackerman, J., and Herzog, M., 2013, Factors influencing breeding waterbird use of islands in San Francisco Bay, 2013 [presentation]: 2013 Science Symposium, Menlo Park, Calif., July 16, 2013, http://southbayrestoration.org/science/2013symposium/presentations /4\%20Hartman\%20SBSPRP\%20Talk_07162013_rtk.pdf.

Hartman, A., Ackerman, J., and M. Herzog, 2015, Salt pond restoration and breeding birds_Enhancing waterbird nest habitat in managed ponds [presentation]: 2015 Science Symposium, Mountain View, Calif., October 22, 2015, http://www.southbayrestoration.org/science/2015symposium/ presentations/12_3_15_Hartman\%20SBSPRP\%20Talk_10212015.pdf.

Hartman, C.A., Ackerman, J.T., Herzog, M.P., Strong, C., Trachtenbarg, D., Sawyer, K.A., and Shore, C.A., 2016, Evaluation of Caspian tern (Hydroprogne caspia) and snowy plover (Charadrius alexandrinus nivosus) nesting on modified islands at the Don Edwards San Francisco Bay National Wildlife Refuge, California-2015 Annual Report: U.S. Geological Survey Open-File Report 20161049, 36 p., http//dx.doi.org/10.3133/ofr20161049. 
Moskal. S.M., Smith, L.M., De La Cruz, S.E.W., Strong, C., and Shaffer, S.A., 2015, Response of waterbirds to island creation within an estuarine ecosystem [poster]: 2015 Science Symposium, Mountain View, Calif., October 22, 2015, http://www.southbayrestoration.org/science/ 2015symposium/posters/2015\%20Moskal\%20SBSP\%20SciSym\%20Poster.pdf.

Pearl, B., Tokatlian, K., and Scullen, J., 2016, Western snowy plover monitoring in the San Francisco Bay annual report 2015: San Francisco Bay National Wildlife Refuge and California Department of Fish and Wildlife, prepared by San Francisco Bay Bird Observatory for Don Edwards, 79 p., http://www.southbayrestoration.org/documents/technical/RU3\%20SNPL\%20Report\%202015.pdf.

Takekawa, J.Y., Smith, L.M., Moskal, S.M., and Piotter, S., 2013, Waterbird response to pond management [presentation]: 2013 Science Symposium, Menlo Park, Calif., July 16, 2013, http://www.southbayrestoration.org/science/2013symposium/ presentations/3\%20Takekawaetal16July2013h.pdf.

Tokatlian, K., 2015, The effects of salt pond restoration on breeding western snowy plovers [presentation]: 2015 Science Symposium, Menlo Park, Calif., October 22, 2015, http://www.southbayrestoration.org/science/2015symposium/ presentations/SBSPRP\%20Symposium_Plover_Tokatlian_nonsync_website.pdf.

Tokatlian, K., Scullen, J., and Burns, C., 2015, Western snowy plover monitoring in San Francisco, Annual Report 2014: Prepared by San Francisco Bay Bird Observatory for Don Edwards San Francisco Bay National Wildlife Refuge and California Department of Fish and Wildlife, 72 p., http://www.southbayrestoration.org/documents/ technical/RU3\%20SNPL\%20Report\%202014_Final.pdf.

Tokatlian, K., Wang, Y., Pearl, B., and Scullen, J., 2016, Oyster shell habitat enhancement for breeding snowy plovers in pond E14, Eden Landing Ecological Reserve, 2015: Report prepared by the San Francisco Bay Bird Observatory for Renee Spenst, Ducks Unlimited, 39 p., http://www.southbayrestoration.org/documents/technical/2015\%20E14\%20Habitat $\% 20$ Enhancement $\% 20$ Report.pdf.

Washburn, N., Burns, C., Ackerman, J., Bluso-Demers, J., Robinson-Nilsen, C., and Strong, C., 2015, California gull population growth and response to restoration in South San Francisco Bay [poster]: 2015 Science Symposium, Mountain View, Calif., October 22, 2015, http://www.southbayrestoration.org/science/2015symposium/posters/ Washburn_Science\%20Symp\%20CAGU\%20poster-2.pdf.

Washburn, N., Scullen, J., and Burns, C., 2015, Managed pond waterbird surveys, September 20132014: Prepared by San Francisco Bay Bird Observatory for Don Edwards San Francisco Bay National Wildlife Refuge and the South Bay Salt Pond Restoration Project 149 p., http://www.southbayrestoration.org/documents/technical/SFBBO $\% 202014 \% 20$ Pond\%20Surveys $\% 20$ Final\%20Report_2015.pdf. 


\section{Mercury}

Ackerman, J., Herzog, M., Harman, A., Eagles-Smith, C., Slotton, D., and Marvin-DiPasquale, M., 2015, Will the South Bay Salt Pond Restoration Project increase mercury in fish and wildlife? [presentation]: 2015 Science Symposium, Mountain View, Calif., October 22, 2015, http://www.southbayrestoration.org/science/2015symposium/ presentations/10_1_45_Ackerman\%20Talk\%20Oct21_2015\%20V3.pdf.

Ackerman, J.T., Herzog, M.P. Hartman, C.A., Watts, T., and Barr, J., 2014, Waterbird egg mercury concentrations in response to wetland restoration in South San Francisco Bay, California: U.S. Geological Survey Open-File Report 2014-1189, 22 p., http://dx.doi.org/10.3133/ofr20141189. Downing-Kunz, M., Callaway, J., Livsey, D., Schoellhamer, D., 2017, Sediment-The macro and micro of patterns in the South Bay [presentation]: Oakland, California, 2017 State of the Estuary Conference, October 10-11, 2017, http://www.southbayrestoration.org/science/ SOE2017presentations-posters/presentations/Downing-KunzandCallawaySOE_forPublicRelease.pdf. Jaffe, B., Foxgrover, A., Fregoso, T., Marvin-DiPasquale, M., Rey, Carlos, Roelvink, D., van der Wegen, M., Achete, F., Shellenbarger, G., and Schoellhamer, D., 2015, Will restoration mobilize mercury in tidal sloughs? [presentation]: 2015 Science Symposium, Mountain View, California, October 22, 2015, http://www.southbayrestoration.org/science/

2015symposium/presentations/9_1_30_Bruce_mercury.pdf.

Foxgrover, A.C., Finlayson, D.P., Jaffe, B.E., and Fregoso, T.A., 2015, Bathymetry and digital elevation models of Coyote Creek and Alviso Slough, South San Francisco Bay, California (ver. 2, March 2014, ver. 3, September 2015: U.S. Geological Survey Open-File Report 2011-1315, 20 p., http://dx.doi.org/10.3133/ofr20111315.

Foxgrover, A., Jaffe, B., and Fregoso, T., 2015, Mapping bathymetric change in Alviso Slough as salt pond restoration projects progress [presentation]: 2015 Science Symposium in Mountain View, California, October 22, 2015, http://www.southbayrestoration.org/science/2015symposium/ posters/Foxgrover_Alviso\%20bathy_symposium_2015.pdf

Marvin-DiPasquale, M., and Cox, M.H., 2007, Legacy mercury in Alviso Slough, South San Francisco Bay, California - Concentration, speciation and mobility: U.S. Geological Survey, Open-File Report 2007-1240, 98 p. [Also available at http://www.southbayrestoration.org/pdf_files/USGS_Legacy_Mercury.pdf.]

Marvin-DiPasquale, M., Schoellhamer, D., Downing-Kunz, M., and Shellenbarger, G., 2013, Mercury in motion-Quantifying mercury flux in Alviso Slough [presentation]: Oakland, California, State of the Estuary Conference, October 29-30, 2013, http://www.southbayrestoration.org/science/SOE2013posters/SotE\%202013\%20Poster\%20$\% 20$ Alviso $\% 20 \mathrm{Hg} \% 20$ flux \%202.pdf.

Fregoso, T.A., Foxgrover, A.C., Jaffe, B.E., and Marvin-DiPasquale, M., 2013, Mercury In motionUsing bathymetric surveys to estimate mercury mobilization from scour of Alviso Slough: Oakland, Calif., 2013 State of the Estuary Conference, October 29-30, 2013, http://www.southbayrestoration.org/science/SOE2013posters/

Fregoso \%20Hg\%20Bathy\%20SOE\%202013.pdf.

Slotton, D., 2017, Mercury-Physical and biological insights [presentation]: Oakland, Calif., 2017 State of the Estuary Conference, October 10-11, 2017, http://www.southbayrestoration.org/science/SOE2017presentationsposters/presentations/Slotton $\% 20$ SOE $\% 20$ Slides $\% 20$ (de-animated).pdf. 


\section{Effects on Aquatic Species}

Cook, J.D., 2016, Spatial and temporal trends of fishes and aquatic invertebrates in a restored salt marsh, San Francisco Estuary, CA: Davis, University of California Master's thesis, 42 p., http://gradworks.umi.com/10/12/10124463.html.

Hobbs, J., 2015, Steelhead smolt outmigration and survival study-Year 2 stream surveys final report: Prepared for Santa Clara Valley Water District, National Oceanic and Atmospheric Administration, National Marine Fisheries Service and the South Bay Salt Pond Restoration Project, 18 p., http://www.southbayrestoration.org/documents/technical/Final\%20Report\%20201415_Guadalupe\%20River\%20Steelhead\%20Smolt\%20Outmigration\%20Study_July2015.pdf. Hob̄̄s, J.A., Cook, J., and Crain, P., 2015, Tidal marsh restoration benefits leopard sharks (Triakis semifasciata) in South Bay Salt Pond Restoration Project Ponds_-Final Report: Prepared for Resource Legacy Fund and South Bay Salt Pond Restoration Project, 32 p., http://www.southbayrestoration.org/documents/ technical/011615 Leopard\%20Shark\%20Chapter FINAL\%20REPORT.pdf

Hobbs, J., Cook, J., and Crain, P., 2016, Draft, Use of Restored Tidal Wetland by Longfin Smelt in the Alviso Marsh, California.

Hobbs, J., Cook, J., Crain, P., and Bisson, M., 2015, Lessons learned from restoring solar evaporation ponds in the San Francisco Estuary [poster]: 2015 Science Symposium in Mountain View, Calif., October 22, 2015, http://www.southbayrestoration.org/science/2015symposium/posters/

HobbsPoster_LessonsLearned_SBSP2015.pdf.

Hobbs, J., Cook, J., Crain, P., Buckmaster, N., Bisson, M., Trites, Emily, Parker, C., and Bess, Z., 2015, Effects on aquatic species and water quality-Will aquatic species be affected by restoration? [presentation]: 2015 Science Symposium in Mountain View, California, October 22, 2015, http://www.southbayrestoration.org/science/2015symposium/presentations/

7_11_30_Hobbs_Effects\%20on\%20Aquatic\%20Species\%20and\%20Water\%20Quality.pdf.

Hobbs, J.A., Cook, J., and La Luz, F., 2014, Steelhead smolt outmigration and survival study_Pond A8, A7 \& A5 entrainment and escapement, final report: Prepared by University of California Davis for the National Marine Fisheries Service, National Oceanic and Atmospheric Administration, and South Bay Salt Pond Restoration Program, http://www.southbayrestoration.org/documents/technical/ Final\%20Report\%202014_Guadalupe\%20River\%20Steelhead\%20Smolt\%20Outmigration\%20Study $\% 20(1)$.pdf.

Hobbs, J., Crain, P., La Luz, F., and Cook, J., 2015, Lessons learned from restoring solar evaporation ponds in the San Francisco Estuary [presentation]: Tidal Wetlands Restoration Symposium, Cal-Neva AFS 2015 Annual Meeting, Santa Cruz, California, DOI: 10.13140/RG.2.1.4782.4886.

Valoppi, L. Hobbs, J., Bourgeois, J., and Mruz, E., 2014, Successes and challenges of fisheries resources in a large restoration project [presentation]: Cal/Neva American Fisheries Society conference in Sacramento, California, March 27 - 29, 2014, http://www.southbayrestoration.org/documents/Valoppi_CalNevaAFS_March_2014-1_Final.pdf. 


\section{Water Quality}

Hobbs, J., Cook, J., Crain, P., Buckmaster, N., Bisson, M., Trites, Emily, Parker, C., and Bess, Z., 2015, Effects on aquatic species and water quality-Will aquatic species be affected by restoration?

[presentation]: 2015 Science Symposium in Mountain View, California, October 22, 2015, http://www.southbayrestoration.org/science/2015symposium/presentations//

7_11_30_Hobbs_Effects\%20on\%20Aquatic\%20Species\%20and\%20Water\%20Quality.pdf.

Novick, E., Downing-Kunz, M., Bresnahan, P., and Senn, D., 2015, Dissolved oxygen in South Bay sloughs [poster]: 2015 Science Symposium in Mountain View, California, October 22, 2015, http://www.southbayrestoration.org/science/2015symposium/posters/

Novick SBSP\%20poster\%202015.pdf.

Senn, D., Novick, E., Downing-Kunz, M., Bresnahan, P., and Holleman, R., 2015, Will water quality be affected? [presentation]: 2015 Science Symposium in Mountain View, California, October 22, 2015 , http://www.southbayrestoration.org/science/2015symposium/presentations/6_1115_Senn_final.pdf.

Shellenbarger, G.G., and Schoellhamer, D.H., 2011, Continuous salinity and temperature data from San Francisco Estuary, 1982-2002: Trends and the salinity-freshwater inflow relationship: Journal of Coastal Research, v. 27, no., p. 1191-1201.

Shellenbarger, G.G., Schoellhamer, D.H., Morgan, T.L., Takekawa, J.Y., Athearn, N.D., and Henderson, K.D., 2008, Dissolved oxygen in Guadalupe Slough and Pond A3W, South San Francisco Bay, California, August and September 2007: U.S. Geological Survey Open-File Report 2008-1097, 26 p., https://pubs.er.usgs.gov/publication/ofr20081097.

Thompson, J.K., and Parchaso, F., 2012, Benthic invertebrate community assessment as a phytoplankton consumer and fish and bird prey source before and after the start of the restoration: Prepared by U.S. Geological Survey for South Bay Salt Pond Restoration Project, Cooperative Agreement 2009-0211, 90 p., http://www.southbayrestoration.org/documents/technical/ Thompson\%20Salt\%20Pond\%20Complete\%20Feb\%202012.pdf.

Topping, B.R., Kuwabara, J.S., Athearn, N.D., Takekawa, J.Y., Parchaso, F., Henderson, K.D., and Piotter, S., 2009, Benthic oxygen demand in three former salt ponds adjacent to south San Francisco Bay, California: U.S. Geological Survey Open-File Report 2009-1180, 21 p.

Topping, B.R., Kuwabara, J.S., Garrett, K.K., Takekawa, J.Y., Parchaso, F., Piotter, S., Clearwater, I., and Shellenbarger, G.G., 2013, Internal nutrient sources and nutrient distributions in Alviso Pond A3W, California: U.S. Geological Survey Open-File Report 2013-1128, 17 p., and data tables, http://pubs.usgs.gov/of/2013/1128/.

\section{Invasive and Nuisance Species}

Ackerman, J.T., Herzog, M.P., Hartman, C.A., and Herring, G., 2014, Forster's tern chick survival in response to a managed relocation of predatory California gulls: The Journal of Wildlife Management, v. 78, no. 5, p. 818-829, http://www.southbayrestoration.org/documents/technical/ Ackerman\%202014\%20JWM\%20tern\%20chick\%20survival.pdf.

Ackerman, J.T., Herzog, M.P., Takekawa, J.Y., and Hartman, C.A., 2014, Comparative reproductive biology of sympatric species-Nest and chick survival of American avocets and black-necked stilts: Journal of Avian Biology, v. 45, p. 609-623.

Ackerman, J.T., Herzog, M.P., Herring, G., Hartman, C.A., Bluso-Demers, J., and Robinson-Nilsen, C., 2013, Impact of salt ponds restoration on California gull displacement and predation on breeding waterbirds - Report for the South Bay Salt Pond Restoration Project and Resources Legacy Fund: U.S. Geological Survey and the San Francisco Bay Bird Observatory, 83 p., http://www.southbayrestoration.org/documents/technical/Gull\%20Report\%20June26_2013_Final.pdf. 
Burns, C.E., Ackerman, J.T., Washburn, N., Bluso-Demers, J., Robinson-Nilsen,C., and Strong, C., 2016, Three decades of California gull population growth and ecological impacts in the San Francisco Bay Estuary: Studies of Western Birds, in press.

Burns, C., and Taketa, E., 2013, California gull population growth and response to Pond A6 breach [presentation]: South Bay Bird Observatory, 2013 Science Symposium in Mountain View, July 16, 2013, http://southbayrestoration.org/science/2013symposium/presentations/

3\%20Burns_ScienceSymposium_Gulls\%202.pdf.

Donehower, C., Tokatlian, K., Robinson-Nilsen, C., and Strong, C., 2013, Western snowy plover monitoring in the San Francisco Bay Annual Report 2012: San Francisco Bay Bird Observatory and U.S. Fish and Wildlife Service, 53 p., http://www.southbayrestoration.org/documents/technical/ RU3\%20SNPL\%20Report\%202012\%20(Jan.\%2031).pdf.

Robinson-Nilsen, C., and Demers, J., 2011, California gull breeding surveys and hazing project, 2011: Prepared for Don Edwards San Francisco Bay National Wildlife Refuge, 7 p., http://www.southbayrestoration.org/documents/technical/SFBBO\%20CAGU\%20Hazing\%20report\% 202011.pdf.

Robinson-Nilsen, C., and Demers, J., 2012, San Francisco Bay Bird Observatory California gull band re-sightings 2011: Prepared by San Francisco Bay Bird Observatory for South Bay Salt Pond

Restoration Project, 1 p., http://www.southbayrestoration.org/documents/technical/ SFBBO \%20banded\%20gull\%20sightings\%20memo.pdf.

\section{Public Access and Wildlife}

Trulio, L., Robinson-Nilsen, C., Sokale, J., and Lafferty, K.D., 2011, Report on nesting snowy plover response to new trail use in the South Bay Salt Pond Restoration Project: Report prepared by San Jose State University for the South Bay Salt Pond Restoration Project, 10 p., http://www.southbayrestoration.org/documents/technical/ Final\%20Snowy\%20Plover\%20Study\%20Report.pdf

Trulio, L., and Sokale, J., 2013, South Bay Salt Pond Restoration Project-Trail user satisfaction study: Report prepared by San Jose State University for the South Bay Salt Pond Restoration Project, 22 p., http://www.southbayrestoration.org/documents/technical/ Trail\%20User\%20Satisfaction\%20Report\%209-21-13\%20(1).pdf.

Trulio, L., Sokale, J., and Chromczak, D., 2013, Experimental study of shorebird response to new trail use in the South Bay Salt Pond Restoration Project: Report prepared by San Jose State University for the South Bay Salt Pond Restoration Project, 15 p., http://www.southbayrestoration.org/documents/ technical/Final\%20Shorebird\%20Report\%20Trulio\%20etal.pdf.

Trulio, L., White, H., Sokale, J., and Tokatlian, K., 2012, Report on waterfowl response to trail use in the South Bay Salt Pond Restoration Project: Report prepared by San Jose State University for the South Bay Salt Pond Restoration Project, 16 p., http://www.southbayrestoration.org/documents/technical/ Final\%20Waterfow1\%20Report\%20Revised\%20July\%202012.pdf. 


\section{Climate Change and Sea Level Rise}

Bever, A.J., MacWilliams, M.L., Wu, Frank, Andes, Lisa, and Conner, C.S., 2014, Numerical modeling of sediment dispersal following dredge material placements to examine possible augmentation of the sediment supply to marshes and mudflats, San Francisco Bay, USA: PIANC (World Association for Waterborne Transport Infrastructure) World Congress, San Francisco, California, June 2014, 18 p.

National Research Council, Division on Earth and Life Studies, Board on Earth Sciences and Resources, Ocean Studies Board, and Committee on Sea Level Rise in California, Oregon, and Washington, 2012, Sea-level rise for the coasts of California, Oregon, and Washington-Past, present, and future: National Research Council of the National Academies, http://nassites.org/americasclimatechoices/other-reports-on-climate-change/sea-level-rise-for-the-coasts-ofcalifornia-oregon-and-washington-past-present-and-future/.

Schile L.M., Callaway, J.C., Morris, J.T., Stralberg, D., Parker, V.T., and Kelly, M., 2014, Modeling tidal marsh distribution with sea-level rise-Evaluating the role of vegetation, sediment, and upland habitat in marsh resiliency: PLoS ONE, no. 9, v. 2, e88760. doi:10.1371/journal.pone.0088760.

Stralberg, D., Brennan, M., J.C., Callaway, J.K., Wood, L.M., Schile, D., Jongsomjit, M., Kelly, V.T., Parker, and S., Crooks, 2011, Evaluating tidal marsh sustainability in the face of sea-level rise: A hybrid modeling approach applied to San Francisco Bay" PLoS ONE 6(11): e27388. doi:10.1371/journal.pone.0027388.

Takekawa, J.Y., Thorne, K.M., Buffington, K.J., Spragens, K.A., Swanson, K.M., Drexler, J.Z., Schoellhamer, D.H., Overton, C.T., and Casazza, M.L., 2013, Final report for sea-level rise response for San Francisco Bay estuary tidal marshes: U.S. Geological Survey Open-File Report 2012-1081, $161 \mathrm{p}$.

Thorne, K.M., Mattsson, B.J., Takekawa, J., Cummings, J., Crouse, D., Block, G., Bloom, V., Gerhart, M., Goldbeck, S., Huning, B., Sloop, C., Stewart, M., Taylor, K., and Valoppi, L., 2015, Collaborative decision-analytic framework to maximize resilience of tidal marshes to climate change: Ecology and Society, v. 20, no. 1, 30 p., http://dx.doi.org/10.5751/ES-07018-200130.

Valoppi, L., Bourgeois, J., Morkill, A., Strong, C., and Krause, J., 2015, Got mud? Planning for sea level rise for the South Bay Salt Pond Restoration Project [poster]: Southwest Climate Summit, Sacramento, California, November 2-3, 2015. 


\section{Appendixes}

Appendixes 1-3 are available for download as PDFs at https://doi.org/10.3133/ofr20181039.

Appendix 1. Summary of Researcher/Manager Meeting, Milpitas, California, March 15, 2016 Appendix 2. Survey of Managers on Phase 1 Studies

Appendix 3. Survey of Researchers on Phase 1 Studies 
Publishing support provided by the U.S. Geological Survey

Science Publishing Network, Tacoma Publishing Service Center

For more information concerning the research in this report, contact the Director, Western Ecological Research Center

U.S. Geological Survey

3020 State University Drive East

Sacramento, California 95819

https://www.werc.usgs.gov/ 
